\title{
Understanding long-term groundwater flow at Pahute Mesa and vicinity, Nevada National Security Site, USA, from naturally occurring geochemical and isotopic tracers
}

\author{
Edward Kwicklis $^{1}$ (D) $\cdot$ Irene Farnham ${ }^{2} \cdot$ Ronald L. Hershey $^{3} \cdot$ Ate Visser $^{4} \cdot$ John Hoaglund III $^{5}$
}

Received: 9 October 2020 / Accepted: 12 August 2021 / Published online: 20 September 2021

(C) The Author(s) 2021

\begin{abstract}
Recently collected naturally occurring geochemical and isotopic groundwater tracers were combined with historic data from the Pahute Mesa area of the Nevada National Security Site (NNSS), Nevada, USA, to provide insights into long-term regional groundwater flow patterns, mixing and recharge. Pahute Mesa was the site of 85 nuclear detonations between 1965 and 1992, many of them deeply buried devices that introduced radionuclides directly into groundwater. The dataset examined included major ions and field measurements, stable isotopes of hydrogen $\left(\delta^{2} \mathrm{H}\right)$, oxygen $\left(\delta^{18} \mathrm{O}\right)$, carbon $\left(\delta^{13} \mathrm{C}\right)$ and sulfur $\left(\delta^{34} \mathrm{~S}\right)$, and radioisotopes of carbon $\left({ }^{14} \mathrm{C}\right)$ and chloride $\left({ }^{36} \mathrm{Cl}\right)$. Analysis of the patterns of groundwater ${ }^{14} \mathrm{C}$ data and the $\delta^{2} \mathrm{H}$ and $\delta^{18} \mathrm{O}$ signatures indicates that groundwater recharge is predominantly of Pleistocene age, except for a few localized areas near major ephemeral drainages. Steep gradients in sulfate $\left(\mathrm{SO}_{4}\right)$ and chloride $(\mathrm{Cl})$ define a region near the western edge of the NNSS where high-concentration groundwater flowing south from north of the NNSS merges with dilute groundwater flowing west from eastern Pahute Mesa in a mixing zone that coincides with a groundwater trough associated with major faults. The ${ }^{36} \mathrm{Cl} / \mathrm{Cl}$ and $\delta^{34} \mathrm{~S}$ data suggest that the source of the high $\mathrm{Cl}$ and $\mathrm{SO}_{4}$ in the groundwater was a now-dry, pluvial-age playa lake north of the NNSS. Patterns of groundwater flow indicated by the combined data sets show that groundwater is flowing around the northwest margin of the now extinct Timber Mountain Caldera Complex toward regional discharge areas in Oasis Valley.
\end{abstract}

Keywords Geochemistry $\cdot$ Groundwater isotopes $\cdot$ Nuclear test site $\cdot$ Pluvial groundwater $\cdot$ USA

\section{Introduction}

Pahute Mesa, located in the northwest corner of the Nevada National Security Site (NNSS), formerly known as the Nevada Test Site, was the location of 85 underground nuclear tests conducted between 1965 and 1992 (US Dept. of Energy 2015; Fig. 1). Many of the underground tests in Pahute Mesa

Edward Kwicklis

Kwicklis@lanl.gov

1 Los Alamos National Laboratory, EES-16, MS T003, Los Alamos, NM 87545, USA

2 Navarro, Las Vegas, NV 89106, USA

3 Desert Research Institute, Reno, NV 89512, USA

4 Lawrence Livermore National Laboratory, Livermore, CA 94550, USA

5 Provenance Geosciences, Las Vegas, NV 89128, USA were conducted close to or beneath the water table, where significant amounts of radioactivity were introduced directly into the groundwater (Laczniak et al. 1996; Finnegan et al. 2016). Tritium $\left({ }^{3} \mathrm{H}\right)$ in groundwater, resulting from underground testing in Pahute Mesa, has now been observed migrating on federally controlled land southwest from the NNSS toward Oasis Valley at concentrations approaching the regulatory limits imposed by the Environmental Protection Agency Safe Drinking Water Act (Code of Federal Regulations 2019). Understanding the complex hydrogeology of this area is therefore critical for forecasting the extent of radionuclides produced by the underground testing.

To provide insight into long-term groundwater flow patterns and flow dynamics, naturally occurring groundwater geochemical and isotopic parameters have been examined. Eleven wells with multiple completions were recently drilled, and a large suite of geochemical and isotopic parameters was analyzed in samples collected from these wells (Navarro 2019; U.S. Dept. of Energy 2019). These wells are located primarily downgradient of underground nuclear tests known 
to have contaminated groundwater. New data from these wells and other wells in their vicinity were combined for this geochemical evaluation (i.e., phase II study area in Fig. 1). Recharge conceptual models based on groundwater isotopic data were also evaluated.

The use of groundwater geochemical and isotopic data to better understand groundwater flow patterns, mixing and recharge has a long tradition in southern Nevada, particularly in areas surrounding the NNSS and Yucca Mountain. Early groundwater geochemical studies focused on using majorion chemistry to distinguish groundwater facies that reflect chemical reactions with tuff or carbonate rocks, or some mixture of the two (Schoff and Moore 1964; Winograd and Thordarson 1975). Pore-water sampling from cores taken from vertical boreholes in tuffs at Rainier Mesa, combined with laboratory water-rock reaction studies, identified the dissolution of volcanic glass and weathering to clays as having a major effect on the pore-water chemistry in tuffs; conversely, micro-crystalline welded tuffs are relatively chemically inert in comparison (White et al. 1980). Later pore-water sampling of tuff cores from vertical boreholes at Yucca Mountain confirmed these findings and highlighted the role of zeolitic tuffs as important rocks for ion exchange in which divalent cations were sorbed to the rocks and monovalent cations were released into the pore water (Yang et al. 1996; Vaniman et al. 2001). Petrographic and mineralogic data from many hundreds of boreholes in the NNSS and Yucca Mountain areas are documented in Warren et al. (2003) and mineralogic and isotopic studies of fracture coatings at Yucca Mountain (Carlos et al. 1995) and Pahute Mesa (Benedict Jr et al. 2000) provide information on the range of minerals and their textural relations typical of these areas. Deep boreholes in alluvium from both Frenchman Flat and Yucca Flat record the slow and ongoing response of the thick ( $>500 \mathrm{~m}$ ) vadose zone in those areas to major climate shifts (Tyler et al. 1996; Walvoord et al. 2002).

Many groundwater studies in southern Nevada have relied on the use of the stable isotopes of oxygen-18 $\left(\delta^{18} \mathrm{O}\right)$ and

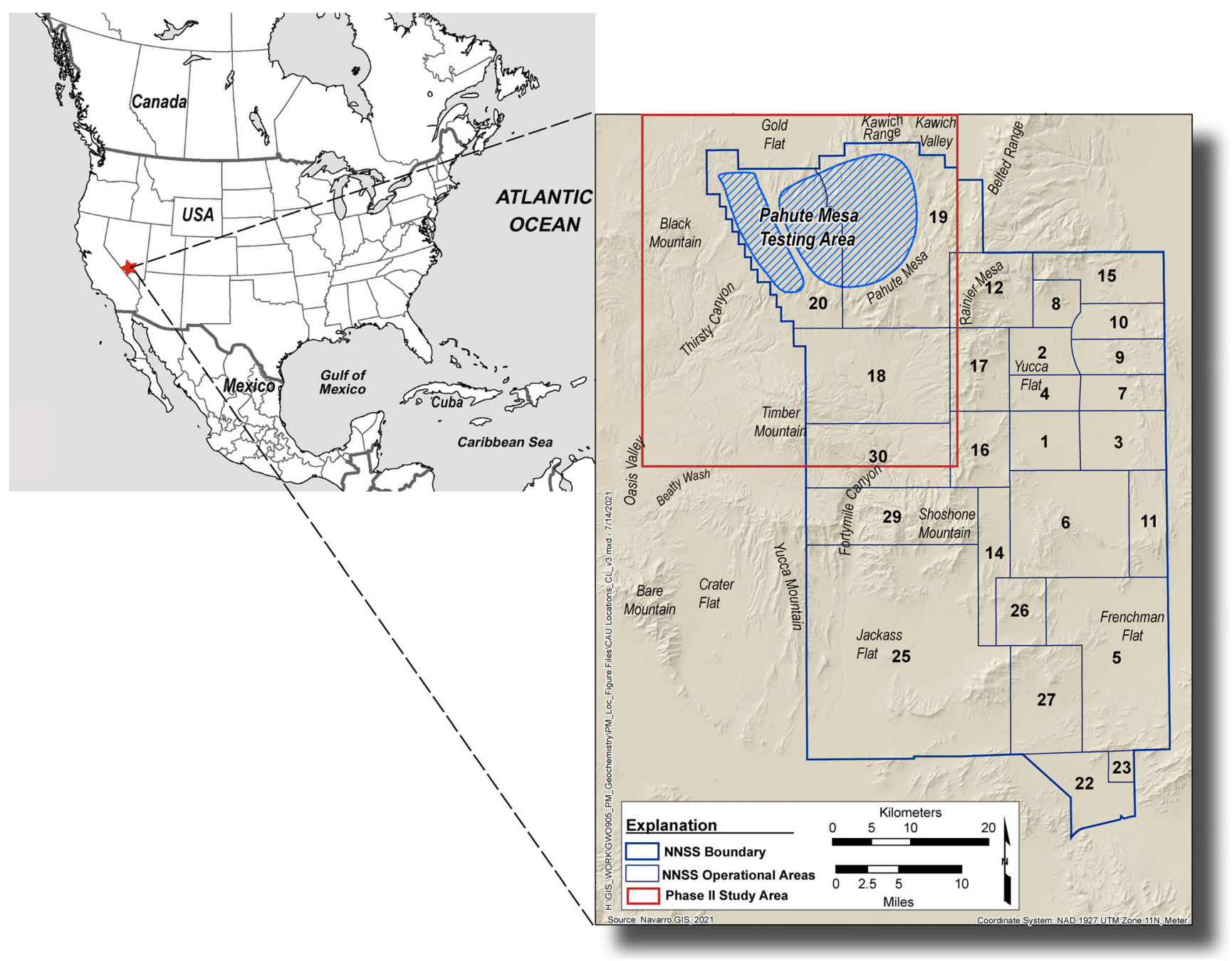

Fig. 1 Location of the Nevada National Security Site (NNSS) and Pahute Mesa. Numbers on the NNSS indicate operational areas 
hydrogen $\left(\delta^{2} \mathrm{H}\right)$ as conservative groundwater tracers to identify flow patterns and modern recharge or paleorecharge. Several regional studies have confirmed that modern recharge is strongly elevation dependent, occurs episodically, and is mainly associated with winter precipitation based on the similarity between the stable isotope composition of winter precipitation and either shallow high-elevation groundwater (Winograd et al. 1998), or perched spring discharge (Ingraham et al. 1991). Benson and Klieforth (1989) studied the dependence of stable isotope composition of modern precipitation on storm track paths and attempted to relate very light stable isotope compositions of groundwater near Yucca Mountain to storm tracks that were expected to prevail at the end of the late Pleistocene when the jet stream was deflected southward by major North American ice sheets. Claassen (1985) and White and Chuma (1987) identified the presence of very isotopically light groundwater in the northern Amargosa Desert and Oasis Valley, which they interpreted to be paleorecharge based on the large differences between the stable isotope composition of the groundwater and modern precipitation and offset from the modern Global Meteoric Water Line (GMWL) of Craig (1961). Studies of layered calcite deposits that have accumulated continuously over the past $560 \mathrm{ka}$ in a cavern at Devils Hole near the Spring Mountains have shown that the $\delta^{18} \mathrm{O}$ of the calcite (accurately dated using U-Th age-dating methods) has been about $2 \%$ lighter during pluvial (glacial) periods compared to interpluvial periods (Winograd et al. 1992).

A number of groundwater geochemical and isotopic studies have been done to evaluate groundwater systems in various areas of the NNSS where nuclear testing took place to help evaluate the rates and directions of groundwater transport of test-related radionuclides (Hershey et al. 2005; SNJV 2006; Hershey et al. 2008). These studies relied on the use of hydraulic-head gradients and relatively conservative anions $\left(\mathrm{Cl}\right.$ and $\left.\mathrm{SO}_{4}\right)$ and stable isotopes $\left(\delta^{18} \mathrm{O}\right.$ and $\left.\delta^{2} \mathrm{H}\right)$ to identify preliminary hypotheses regarding potential groundwater flow paths. These potential flow paths were then further evaluated with inverse geochemical models such as NETPATH (Plummer et al. 1994) or PHREEQC (Parkhurst and Appelo 1999) to determine if plausible mixing and water-rock reactions could be identified that would explain the downgradient evolution of both the nonreactive and reactive chemical and isotopic species. The mixing and reaction models were also used to account for the effects of mineral carbon introduced by water-rock reactions along the flow paths to correct the travel times estimated from ${ }^{14} \mathrm{C}$ activities. Early work (Thomas et al. 2002; Kwicklis et al. 2005; Rose et al. 2006) and more recent work done for the testing areas at Pahute Mesa (Navarro 2020) in support of this report follows the same strategy. The early Pahute Mesa area (phase I) studies are described in considerable detail in section 'Previous geochemical investigations for Pahute Mesa' to provide a more regional perspective than was possible from the current (phase II) study alone, which focused on areas in western Pahute Mesa where radionuclides produced by nuclear testing are now migrating off the NNSS.

\section{Hydrogeologic setting}

\section{Precipitation and infiltration}

Estimated average annual precipitation and net infiltration for an area comprising the phase II Pahute Mesa-Oasis Valley (PM-OV) infiltration model domain are shown in Figs. 2 and 3, respectively (Middleton et al. 2019). Precipitation for the study area was estimated from 26 meteorological stations active between 1960 and 2014, with some stations active for as long as 55 years. Precipitation from these stations was interpolated both spatially and with elevation to produce the map of average annual precipitation shown in Fig. 2. The map of precipitation shows a strong elevation dependence, with the highest estimated values occurring in eastern Pahute Mesa, Rainier Mesa, Timber Mountain and Shoshone Mountain; and the lowest estimated values in the southwest corner of the infiltration model domain near Oasis Valley and north of Pahute Mesa in Gold Flat. Western Pahute Mesa receives significantly less precipitation than eastern Pahute Mesa because of its lower elevation, as inferred from a local precipitation station with significantly less average annual precipitation than stations to the east.

Average annual net infiltration (i.e., infiltration that drains below a depth where it can be removed by evaporation or plants) is shown in Fig. 3. As described in Middleton et al. (2019), average annual net infiltration is calculated from 54 years of daily water-balance calculations at slightly more than 1 million $50 \times 50-\mathrm{m}$ computational cells. The daily water balance at each cell includes daily precipitation and temperature interpolated from the meteorological stations, run-off and run-on from neighboring cells, evapotranspiration, sublimation (if snow is present), changes in soil water storage, and deep drainage (net infiltration). As indicated in Middleton et al. (2019), maps of average annual net infiltration do not reflect the fact that net infiltration happens only intermittently, and typically only every few years during a few months in late winter and early spring when evapotranspiration is low and short-term precipitation can overcome the potential evapotranspiration (PET; Flint et al. 2004). Nonetheless, the map of net infiltration indicates average annual net infiltration rates are relatively large in the high-elevation areas of Pahute Mesa, along north-facing slopes, and along both minor and major drainages. Lower elevation areas and areas underlain by thick alluvium (considered as a bedrock type in the models) had negligible net infiltration, consistent with dozens of shallow borehole chloride profiles from the model area that indicate 
Fig. 2 Average annual precipitation for the Pahute MesaOasis Valley (PM-OV) infiltration model domain (modified from Middleton et al. 2019)

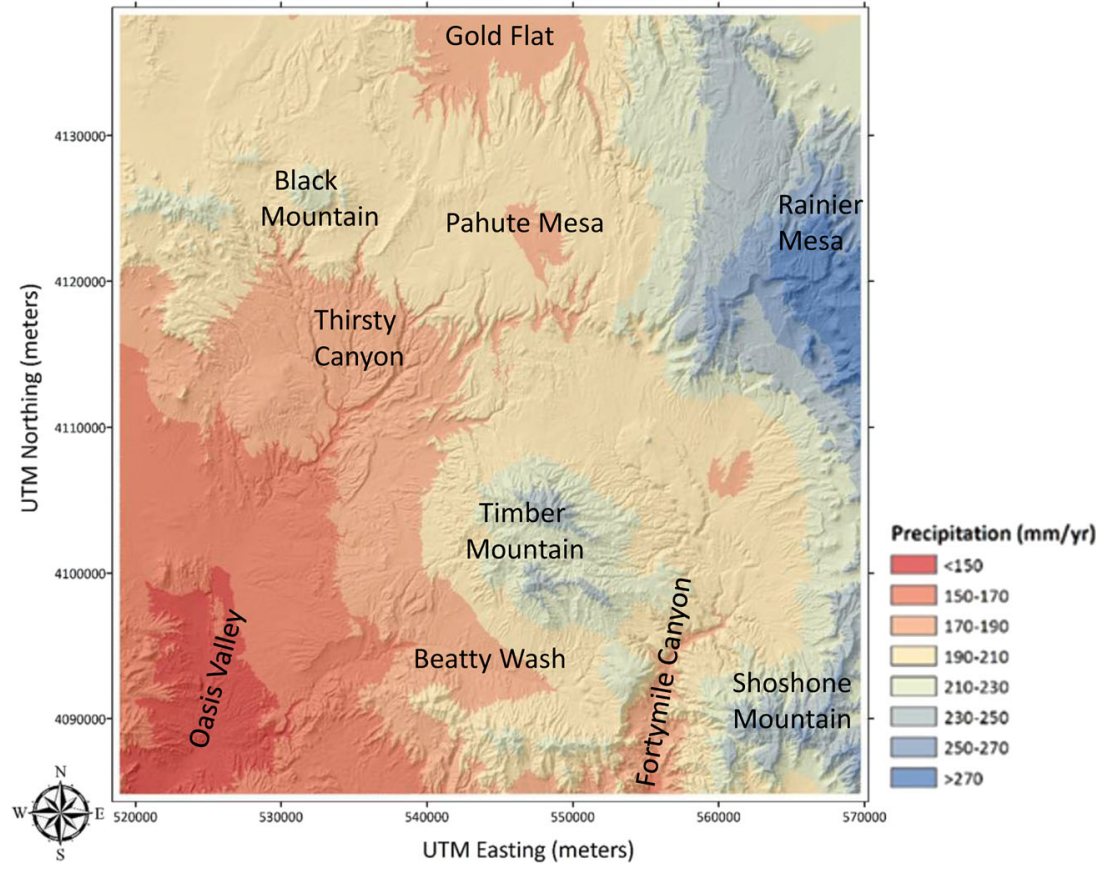

little or no net infiltration below the root zone in thick alluvium (Russell and Minor 2002). The net infiltration map results from the interaction of many factors, including soil and bedrock properties, depth of alluvium, type and density of vegetation cover, and slope magnitude and aspect.

Middleton et al. (2019) noted that present-day net infiltration under Pahute Mesa might not reach the water table for thousands of years because of the thick ( $>600 \mathrm{~m}$ ) unsaturated zone present throughout most of its area. However, the same controls on the distribution of net infiltration (e.g., elevation dependence of precipitation and spatial distribution of soil and bedrock type) have been in place for many thousands of years, so the overall pattern of groundwater recharge at the water table probably reflects the pattern of present-day net infiltration shown in Fig. 3, despite the delay that occurs between net infiltration and groundwater recharge.

\section{Flow system}

The PM-OV groundwater flow system discharges primarily at Oasis Valley, where low-permeability rocks force groundwater to the surface at a series of springs and seeps, some of
Fig. 3 Average annual net infiltration for the PM-OV infiltration model domain (modified from Middleton et al. 2019)

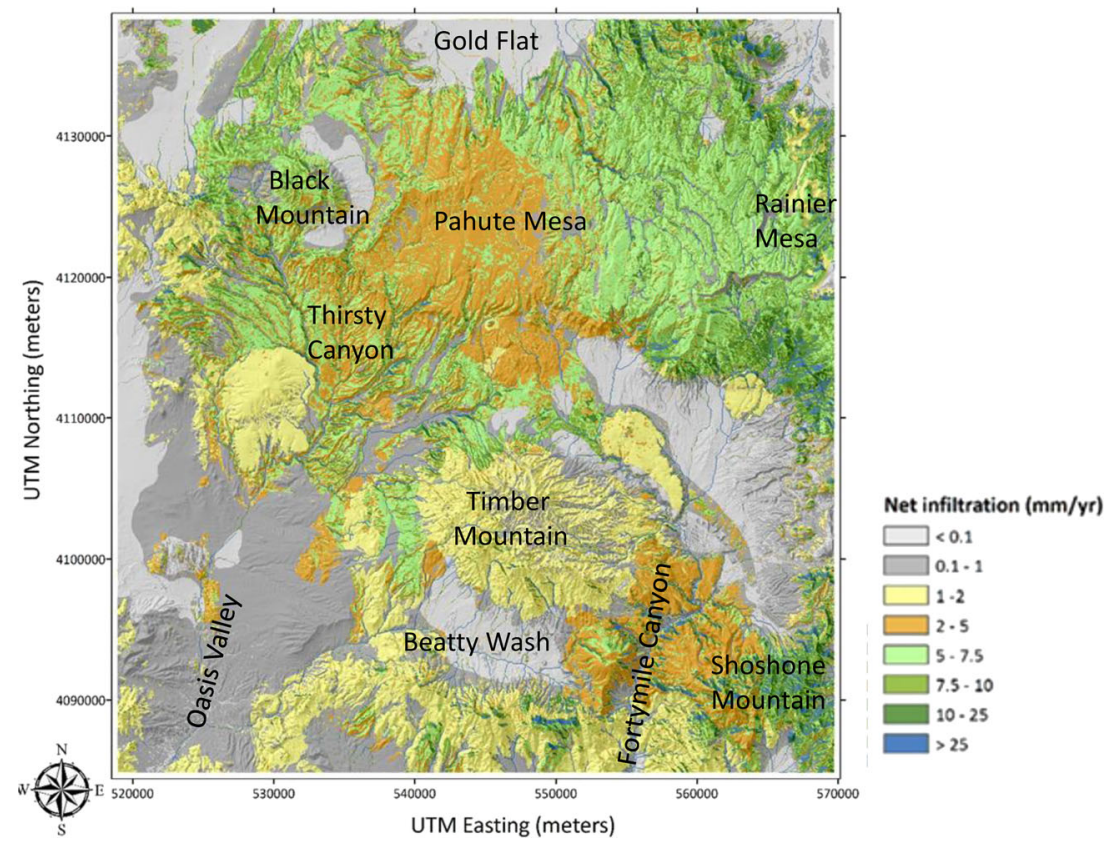


which flow as surface water along the Amargosa River channel before reinfiltrating into the stream bed. Reiner et al. (2002) estimated the average annual discharge near Oasis Valley to be about 7.3 million cubic meters per year $\left(\mathrm{m}^{3} /\right.$ year). Based on water-balance constraints and hydraulic-head contours, Fenelon et al. (2016) estimated boundaries for the PMOV groundwater flow system that indicated that all groundwater flowing beneath Pahute Mesa ultimately discharges at Oasis Valley.

Hydraulic-head contours are shown in Fig. 4 along with the known volcanic caldera boundaries and fault traces at the water table. Hydraulic-head gradients shown in Fig. 4 indicate that groundwater flow in eastern Pahute Mesa is predominantly to the west or southwest. West of the NNSS boundary, groundwater flow is inferred to be dominantly to the south or southeast, but data in the northwest portion of the map area are sparse. A groundwater trough exists in western Pahute Mesa where groundwater flow from the east and west converges. The groundwater trough may be associated with the Purse and West Purse faults or the Thirsty Canyon lineament on the west, and the West Boxcar and Boxcar faults on the east, which appear to limit groundwater flow into the trough. The axis of the trough roughly coincides with the ER-20-7 fault, which, if sufficiently permeable, could function as a drain. East of the trough, hydraulic gradients have a stronger north-south component between the Boxcar and West Greeley faults, indicating dominantly southerly flow in this area.

From the hydraulic-head contours shown in Fig. 4, groundwater flow appears to converge toward the Oasis Valley discharge area from the west, north, and east. Timber Mountain is assumed to be part of the southern boundary of the PM-OV groundwater flow system provided there are low-permeability rocks restricting flow beneath the mountain or sufficient recharge to create a groundwater mound (Jackson et al. 2021; Hershey et al. 2020; Fenelon et al. 2016, 2010). Although no wells currently exist beneath Timber Mountain to confirm the presence of either low-permeability rocks or a recharge mound, these features could contribute to the reorientation of flow from Pahute Mesa around the northwest margin of Timber Mountain. Alternatively, hydraulic-head contours steepen toward the southern boundary of the map area suggesting that north-south flow from Pahute Mesa beneath Timber Mountain may be precluded by structural and stratigraphic features to the south of Timber Mountain, perhaps associated with the Claim Canyon caldera as opposed to features associated with the Timber Mountain caldera complex (TMCC) itself. This interpretation is also based on the observation that similarly steep hydraulic gradients do not exist along the northern boundary of the TMCC. Because groundwater movement could be blocked by barriers directly south of Timber Mountain, groundwater from Pahute Mesa may dam up north of the barrier and flow around the northwest side of Timber Mountain toward lower Beatty Wash and Oasis Valley.

\section{Geology and hydrostratigraphy}

The geology of the Pahute Mesa area is extremely complex and includes tuffs and lavas that were erupted from as many as seven overlapping volcanic centers within the Southwest Nevada Volcanic Field between 16 and 7 million years ago (Sawyer et al. 1994). As elsewhere at the NNSS, the volcanic rocks in the Pahute Mesa area have been classified as aquifers and confining units based on their typical water-transmitting properties, which in general reflects their tendency to fracture as they cool and during later tectonic events (Prothro et al. 2009; US Dept. of Energy 2020). Welded tuffs and lavas tend to be the most permeable rocks and are designated as aquifers, whereas porous, altered zeolitic rocks are generally the least permeable rocks and are considered confining units. However, individual rock types exhibit considerable internal heterogeneity and substantial overlap with other rock types in both their measured and model-calibrated permeabilities (Fenelon et al. 2016; Garcia et al. 2017; Frus and Halford 2018; Halford and Jackson 2020). Given that for almost all hydrostratigraphic units (HSUs), the permeability of the rock matrix is very low compared to the bulk-rock permeability, the variability in bulk-rock permeability can be reasonably attributed to spatial variations in the density, openness, and interconnectedness of fractures.

The combination of hydrostratigraphic layering and offset along structural features produces a highly complex distribution of HSUs (Fig. 5) and, potentially, of groundwater flow paths, as reflected by vertical differences in water chemistry in individual boreholes. In complex hydrogeologic settings such as this, groundwater chemical and isotopic compositions can provide an important independent check on flow system interpretations based on hydraulic arguments. In particular, multivariate hydrochemical analyses that focus on similarities and difference in groundwater composition can provide evidence of where flow paths converge and diverge in three dimensions - see electronic supplemental materials (ESM). This understanding of the depth-dependent nature of groundwater compositions, combined with HSU distributions, may help to guide the development of future groundwater monitoring networks.

\section{Previous geochemical investigations for Pahute Mesa}

A series of geochemical investigations was completed as part of a phase I characterization of the PM-OV groundwater flow system (Thomas et al. (2002), Rose et al. (2006), and Kwicklis et al. (2005)). The phase I studies were intended to investigate 

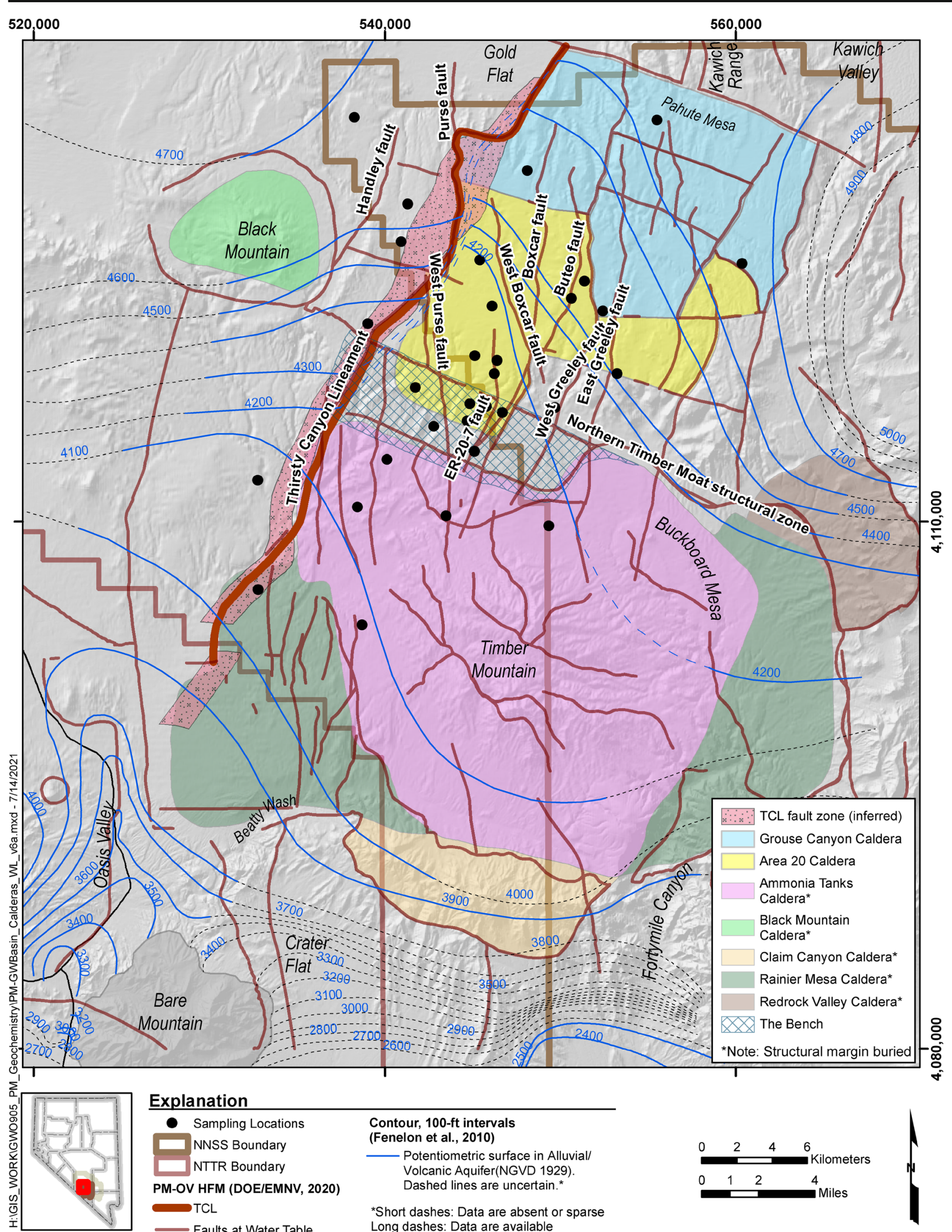

Explanation

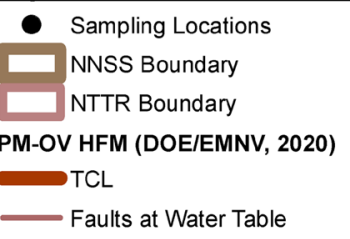

Source: Navarro GIS, 2021
Contour, 100-ft intervals

(Fenelon et al., 2010)

- Potentiometric surface in Alluvial/ Volcanic Aquifer(NGVD 1929) Dashed lines are uncertain.*

*Short dashes: Data are absent or sparse Long dashes: Data are available

(contour based on conceptual interpretation)

Fig. 4 Pahute Mesa calderas and hydraulic-head contours from Fenelon et al. (2010) 


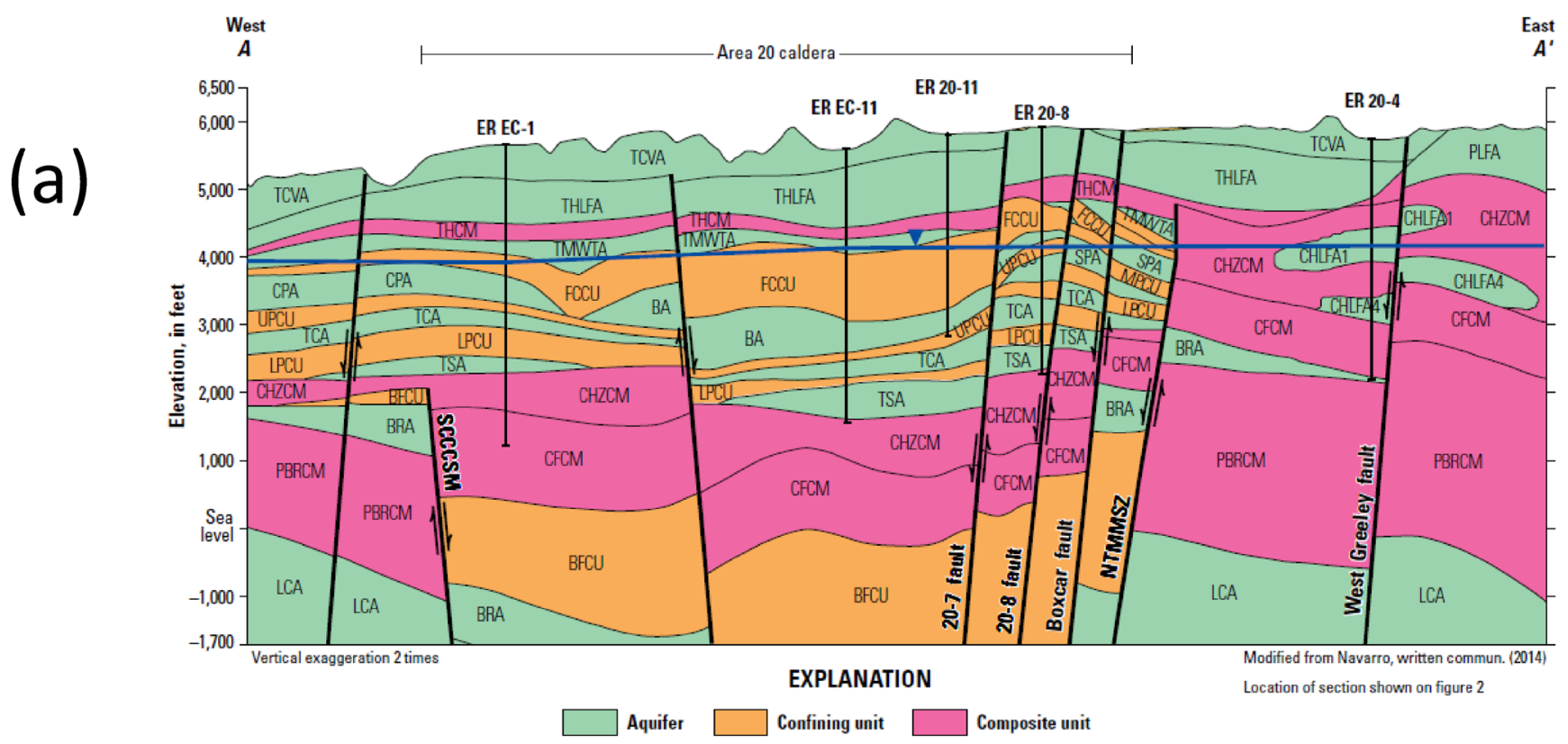

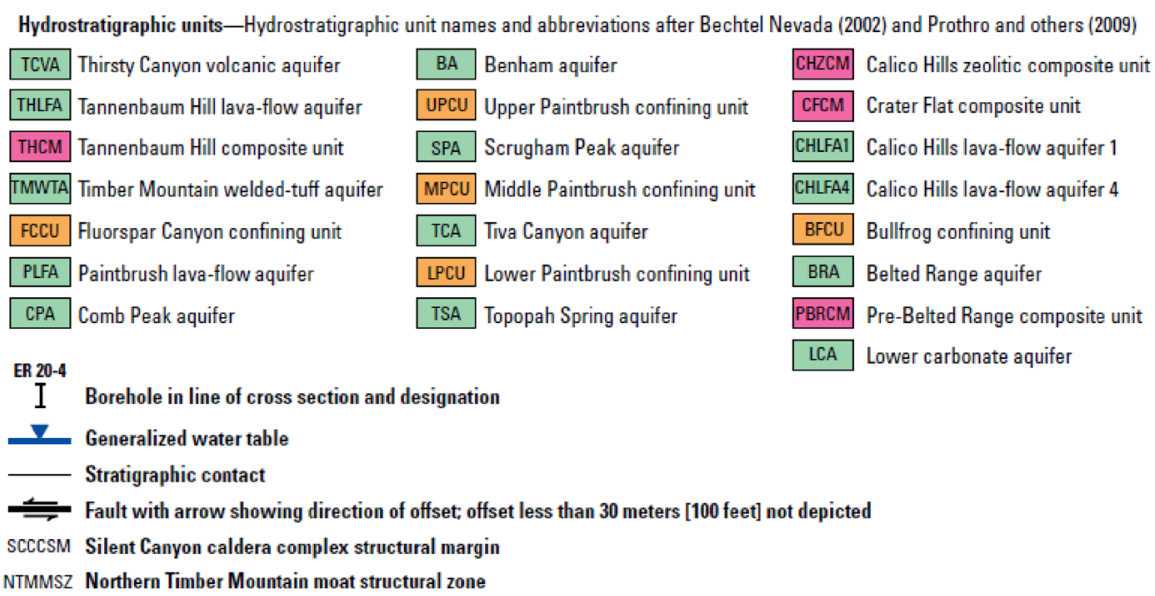

Fig. 5 Cross sections through the Pahute Mesa Bench area a east-west and b north-south (modified from Garcia et al. 2017)

the regional relationships between groundwater found at Pahute Mesa and areas to the south, particularly at regional discharge areas in Oasis Valley. These early studies drew similar overall conclusions with some minor differences between the earlier and later studies. The current study summarizes the later Kwicklis et al. (2005) study.

Sampling locations categorized by the geographic area, and the relationship between $\delta^{2} \mathrm{H}$ and $\mathrm{Cl}$ in groundwater from Kwicklis et al. (2005) are shown in Figs. 6 and 7, respectively. Based on the $\delta^{2} \mathrm{H}$ and $\mathrm{Cl}$ data shown in Fig. 7, three distinct groundwater types were observed in this area: (1) groundwater with relatively light $\delta^{2} \mathrm{H}$ compositions and high $\mathrm{Cl}$ concentrations in the northernmost Thirsty Canyon area (e.g., ER-EC-1 and ER-EC-4); (2) groundwater with relatively light $\delta^{2} \mathrm{H}$ compositions, but relatively dilute $\mathrm{Cl}$ concentrations in Pahute Mesa (e.g., U-20 WW, UE-19 h, and UE-19c WW); and (3) groundwater with relatively dilute $\mathrm{Cl}$ and heavier $\delta^{2} \mathrm{H}$ compositions in upper Fortymile Wash area (e.g., UE-29a\#1 and
UE-29a\#2). Some groundwater in upper Fortymile Wash area (e.g., ER-18-2) has distinctly lighter $\delta^{2} \mathrm{H}$ compositions and somewhat more concentrated $\mathrm{Cl}$ than typical groundwater from the area, suggesting multiple sources of groundwater in this area.

The compositions of other groundwaters in the PM-OV flow system are generally intermediate between these endmember compositions, and therefore are potentially a mixture of groundwater from these sources - for, instance, the $\mathrm{Cl}$ concentration and $\delta^{2} \mathrm{H}$ composition of most Thirsty Canyon area groundwaters appear to lie along a trend defined by data from ER-EC-1 and ER-EC-4 and wells from the Pahute Mesa area (Fig. 7). Downgradient of Thirsty Canyon, many Oasis Valley area groundwater samples appear to lie along the same trend in $\mathrm{Cl}$ concentration but have a somewhat heavier $\delta^{2} \mathrm{H}$ composition, suggesting that an isotopically heavier component has mixed with Thirsty Canyon groundwater in the Oasis Valley area. Potential sources of this isotopically heavier component 


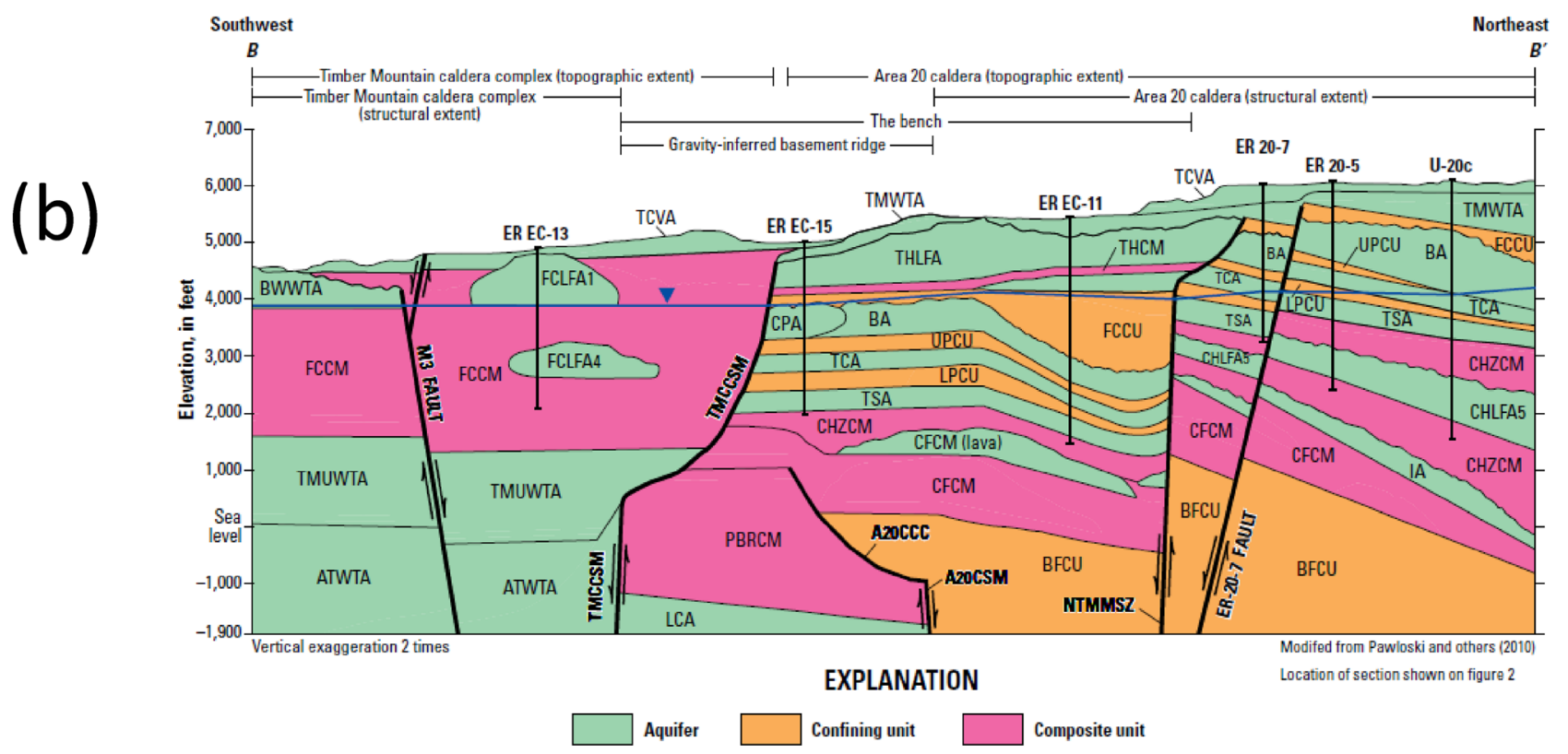

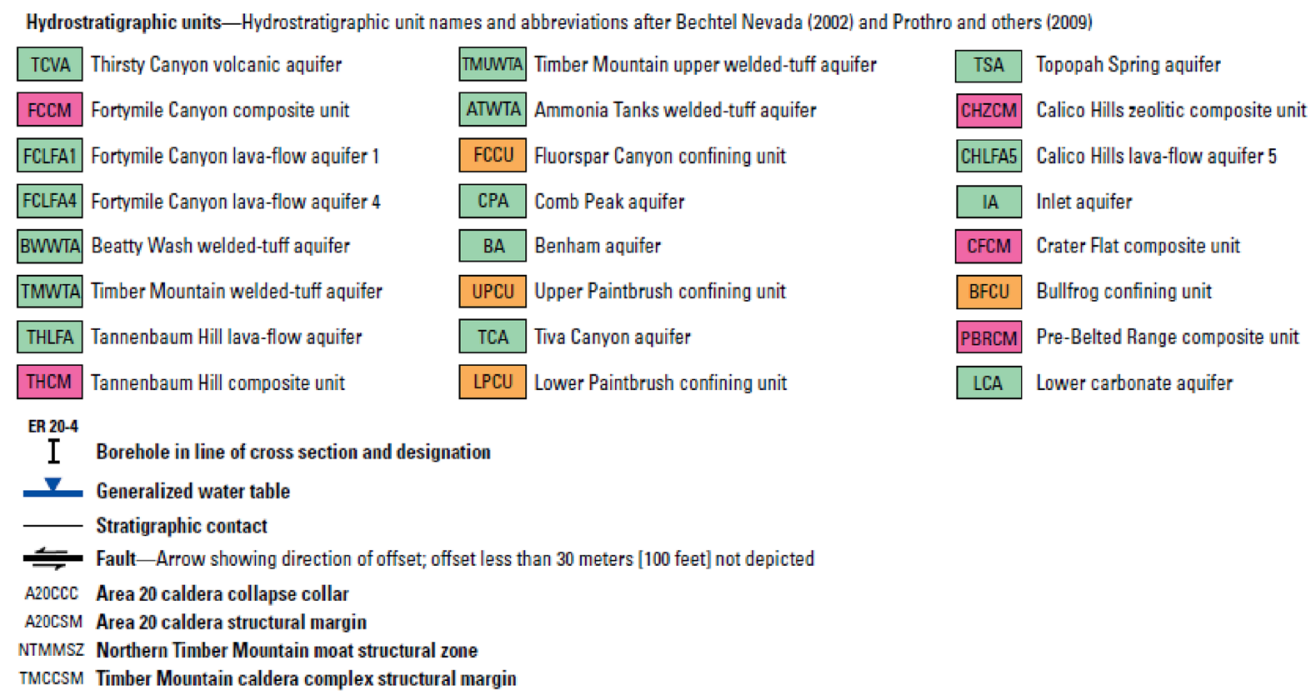

Fig. 5 continued.

include minor amounts of local recharge from surface runoff, groundwater flow from the north in the Tolicha Peak area, or groundwater from north of the NNSS.

These trends suggest that dilute groundwater flowing west or southwest from high-elevation recharge areas on eastern Pahute Mesa mixes with more concentrated groundwater from Gold Flat in western Pahute Mesa and the Thirsty Canyon area. Further downgradient of Thirsty Canyon toward Oasis Valley, additional unmixed dilute groundwater from eastern Pahute Mesa merges with the mixed Thirsty Canyon groundwater toward the discharge area in Oasis Valley, so that the total percentage of Pahute Mesa groundwater discharging at Oasis Valley increases southward.

Groundwater $\mathrm{Cl}$ and $\mathrm{SO}_{4}$ concentrations are relatively constant southward from Pahute Mesa through Timber Mountain and into the Yucca Mountain area, so that groundwater flow between these areas cannot be dismissed based on $\mathrm{Cl}$ and $\mathrm{SO}_{4}$ alone (Fig. 8). However, the distribution of groundwater $\delta^{2} \mathrm{H}$ and $\delta^{18} \mathrm{O}$ compositions, combined with inverse groundwater mixing and reaction models (Kwicklis et al. 2005), indicates that isotopically lighter groundwater from Pahute Mesa flows around the western margin of the resurgent Timber Mountain dome toward Thirsty Canyon and Oasis Valley, with some unknown, but probably minor amount of groundwater possibly flowing through lower Beatty Wash into northwestern Crater Flat. Groundwater beneath Fortymile Wash, upper Beatty Wash, and Yucca Mountain is too isotopically heavy to include a large fraction of groundwater from Pahute Mesa and appears to be dominated by local recharge. It also does not appear that the dominant direction of groundwater flow from 


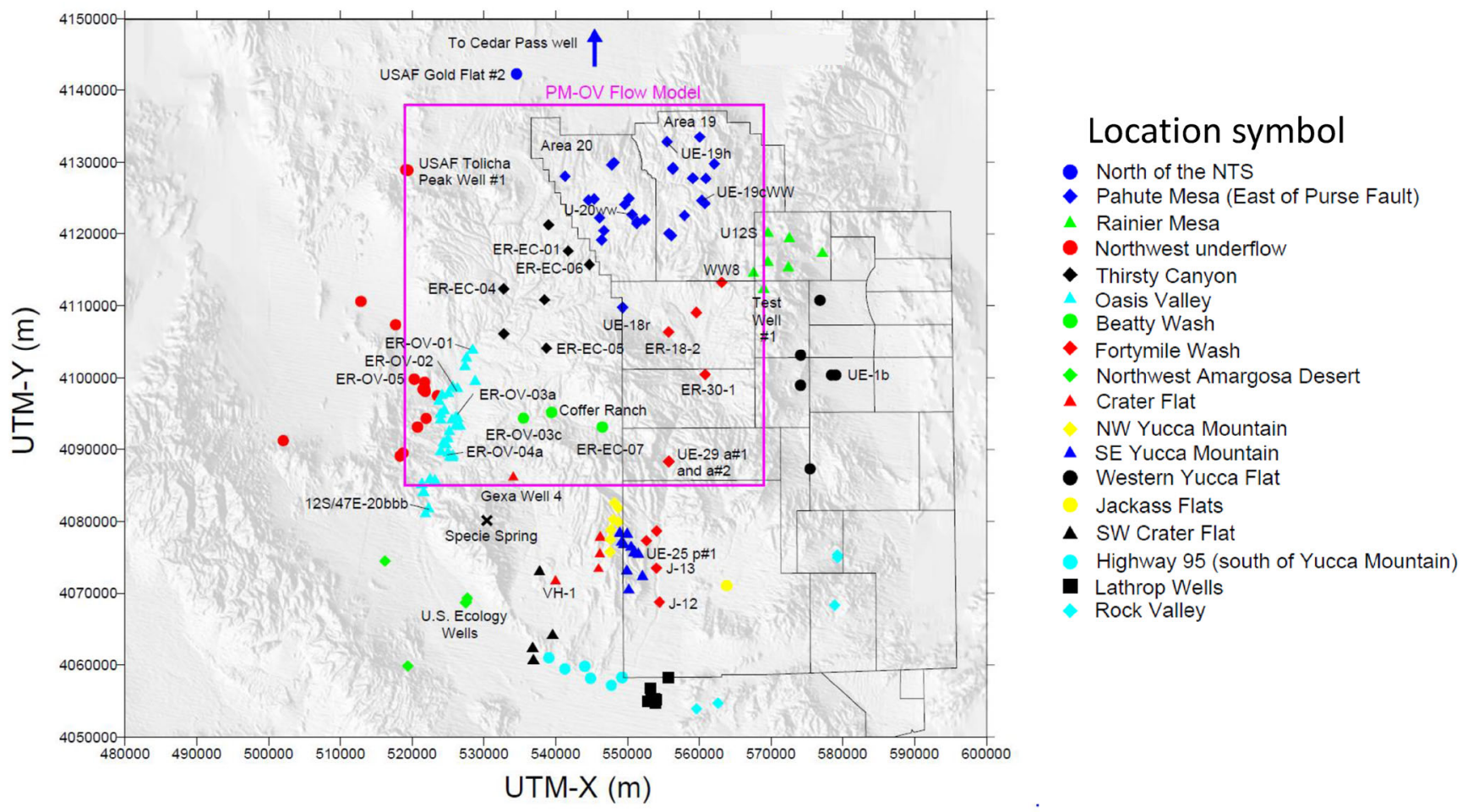

Fig. 6 Key wells used for phase I PM-OV geochemistry investigations

upper Beatty Wash is down the wash toward Oasis Valley; rather, the distributions of $\delta^{2} \mathrm{H}$ and $\delta^{18} \mathrm{O}$ compositions suggest that groundwater from upper Beatty Wash flows southeast through northeast Yucca Mountain toward Fortymile Wash (Fig. 8).

The groundwater $\delta^{2} \mathrm{H}$ and $\delta^{18} \mathrm{O}$ values from the Kwicklis et al. (2005) study are shown in Fig. 9, along with the GMWL of Craig (1961) and a local meteoric water line from Yucca Mountain precipitation (YM-LMWL; Moscati and Scofield 2011). The volume-weighted mean winter precipitation collected on Yucca Mountain between 2006 and 2009 is also shown (Fig. 9). The majority of the groundwater samples from the study are much lighter than the present-day mean winter values and plot well below the GMWL or YM-LMWL, suggesting that, except near major drainages, most of the groundwater in the area was recharged under cooler pluvial climate. Earlier analysis of groundwater $\delta^{2} \mathrm{H}$ and $\delta^{18} \mathrm{O}$ in the area by White and Chuma (1987) suggested that the offset of Oasis Valley area groundwater from the present-day GMWL was because the deuterium excess $(10 \%)$ in the GMWL was
Fig. $7 \delta^{2} \mathrm{H}$ versus $\mathrm{Cl}$ for the wells included in the phase I PM-OV investigation

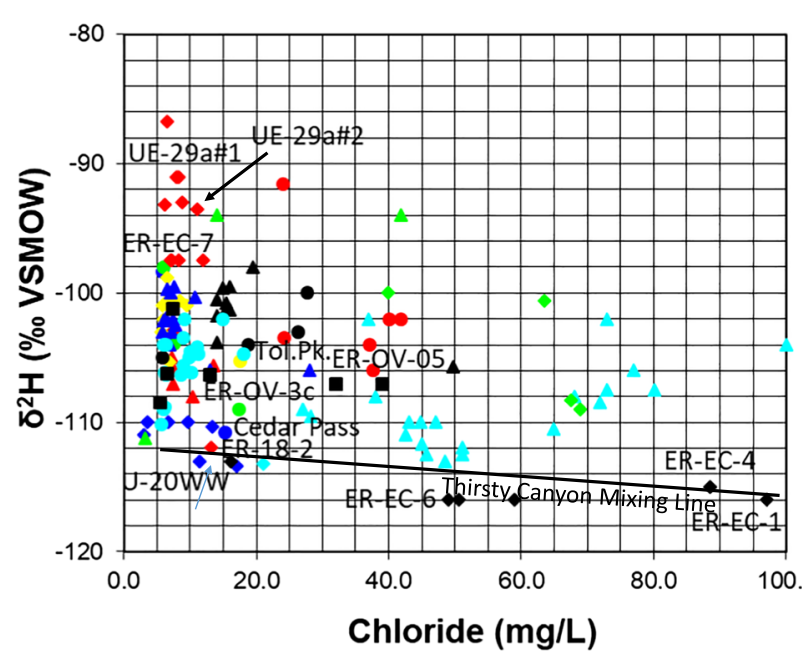

- North of NTS

- Pahute Mesa

$\triangle$ Rainier Mesa

- NW underflow

- Thirsty Canyon

$\triangle$ Oasis Valley

- Beatty Wash

- Fortymile Wash

- NW Amargosa

$\Delta$ Crater Flat

NW Yucca Mountain

- SE Yucca Mountain

- W Yucca Flat

Jackass Flats

$\Delta$ SW Crater Flat

- Highway 95

- Lathrop Wells

- Rock Valley 

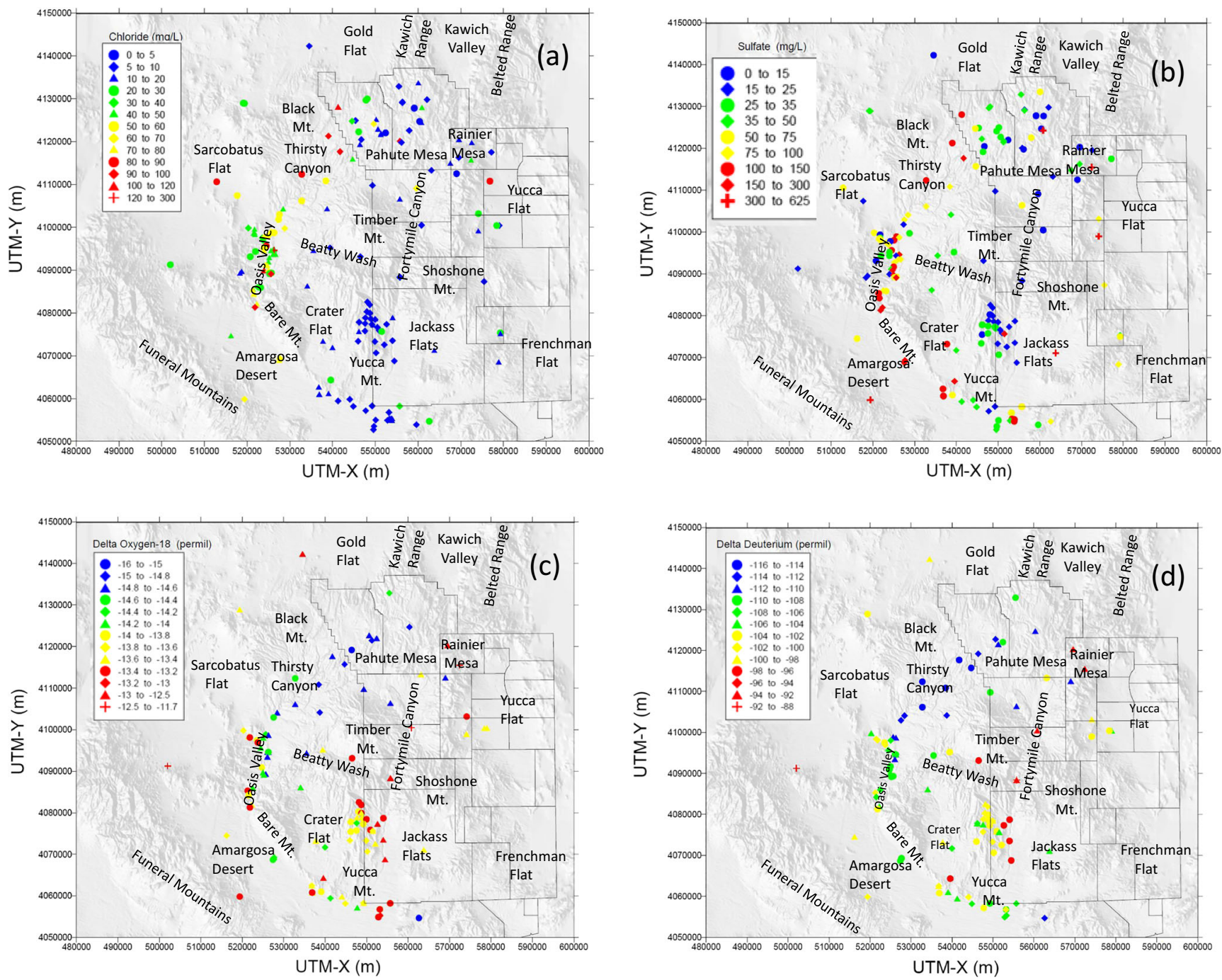

Fig. 8 Spatial trends within the PM-OV flow system: a Cl, b $\mathrm{SO}_{4}, \mathbf{c} \delta^{18} \mathrm{O}$, and $\mathbf{d} \delta^{2} \mathrm{H}$

Fig. $9 \delta^{2} \mathrm{H}$ versus $\delta^{18} \mathrm{O}$ for the wells included in the phase I PM$\mathrm{OV}$ investigation (Modified from Kwicklis et al. 2005)
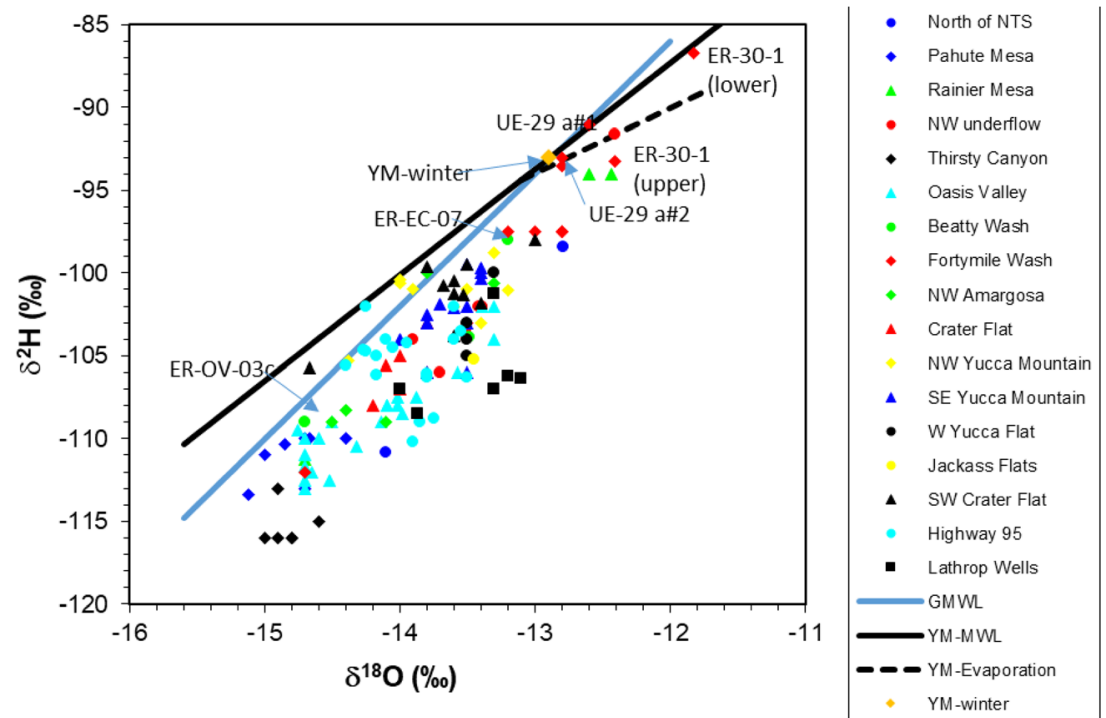
smaller in past climates (Merlivat and Jouzel 1979) because of lower water vapor pressures over the oceans during the ice age.

Groundwater ${ }^{14} \mathrm{C}$ ages were calculated by Kwicklis (2009) using chemical and $\delta^{13} \mathrm{C}$-based correction methods to correct for the incorporation of ${ }^{14} \mathrm{C}$-free ("dead") carbon through calcite dissolution and isotopic exchange. Combining the corrected ${ }^{14} \mathrm{C}$ ages of Kwicklis (2009) with the $\delta^{2} \mathrm{H}$ and $\delta^{18} \mathrm{O}$ data, Middleton et al. (2019) showed a clear relation between groundwater $\delta^{2} \mathrm{H}$ and $\delta^{18} \mathrm{O}$ and corrected groundwater age in the infiltration study area (Fig. 10). Non-Oasis Valley samples display a general relationship between age and isotopic composition that indicates recharge has become heavier (by about $2 \% \circ$ in $\delta^{18} \mathrm{O}$ and $20 \%$ in $\delta^{2} \mathrm{H}$ ) since the late Pleistocene. Winograd et al. (1992 and 2006) showed from uranium-dated calcite deposits at Devils Hole in Ash Meadows that the $\delta^{18} \mathrm{O}$ values of groundwater recharge in southern Nevada have typically been about $2 \%$ o heavier during interpluvial periods compared with the preceding pluvial periods over the last 560,000 years. Using the modern GMWL slope of 8 between $\delta^{2} \mathrm{H}$ and $\delta^{18} \mathrm{O}$ values of precipitation (Craig 1961), the transition from a pluvial to interpluvial period would have resulted in an approximately $16 \%$ increase in $\delta^{2} \mathrm{H}$ values, consistent with the observed range in groundwater $\delta^{2} \mathrm{H}$.

In the vicinity of the NNSS, the transition from the last pluvial to the present interpluvial occurred about 10,000 years ago, based on plant remains preserved in packrat middens (Forester et al. 1999). The trend between $\delta^{2} \mathrm{H}$ and $\delta^{18} \mathrm{O}$ values and corrected ${ }^{14} \mathrm{C}$ age may be because of the mixing of older water with light isotopic compositions and more recent recharge with a heavier isotopic composition and does not necessarily reflect transitions in the isotopic composition of precipitation over time. The volume-weighted mean $\delta^{18} \mathrm{O}$ $(-12.9 \%)$ and $\delta^{2} \mathrm{H}(-93 \%$ ) values of modern winter precipitation from Yucca Mountain (Moscati and Scofield 2011) are shown in Fig. 10 for comparison. The groundwater isotopic data are generally much lighter than the $\delta^{18} \mathrm{O}$ and $\delta^{2} \mathrm{H}$ of the mean winter precipitation at Yucca Mountain, except near Fortymile Wash.

The relationship between isotopic composition and calculated groundwater ${ }^{14} \mathrm{C}$ age is different for the Oasis Valley samples because the ${ }^{14} \mathrm{C}$ ages of the shallow groundwater have likely been reset by interaction with modern soil $\mathrm{CO}_{2}$ near the Oasis Valley discharge area, whereas the $\delta^{2} \mathrm{H}$ and $\delta^{18} \mathrm{O}$ are inherited from the isotopically light, late Pleistocene groundwater upgradient in Thirsty Canyon and Pahute Mesa. Additionally, a small amount of modern recharge similar to shallow Fortymile Canyon groundwater may mix with older, upgradient groundwater from Thirsty Canyon in the Oasis Valley area (Kwicklis et al. 2005).

\section{Current (phase II) data summary}

The regional groundwater system south of Pahute Mesa was reasonably well known by the end of phase I through a combination of hydrogeologic characterization, modeling, and geochemistry. The current (phase II) geochemistry study adds detail to the understanding of the flow system in western Pahute Mesa and provides a perspective on the causes for the steep gradient in $\mathrm{Cl}$ and $\mathrm{SO}_{4}$, which was left unexplained at the end of phase I. By providing insight into the details of the flow system in western Pahute Mesa, which forms the leading edge of contaminant migration off the NNSS, the current work may also be useful for siting monitoring wells.

The current (phase II) geochemical investigation focuses on a smaller area where new data have been collected from a series of new wells and from resampling wells included in the previous investigations (Fig. 11). These new data are then integrated with the regional understanding established by the phase I studies to refine the understanding of groundwater flow at and south of Pahute Mesa. The first step in this process was the development of a dataset that best represents the groundwater chemistry from each sampled completion interval for each well within the current study area (see the ESM).
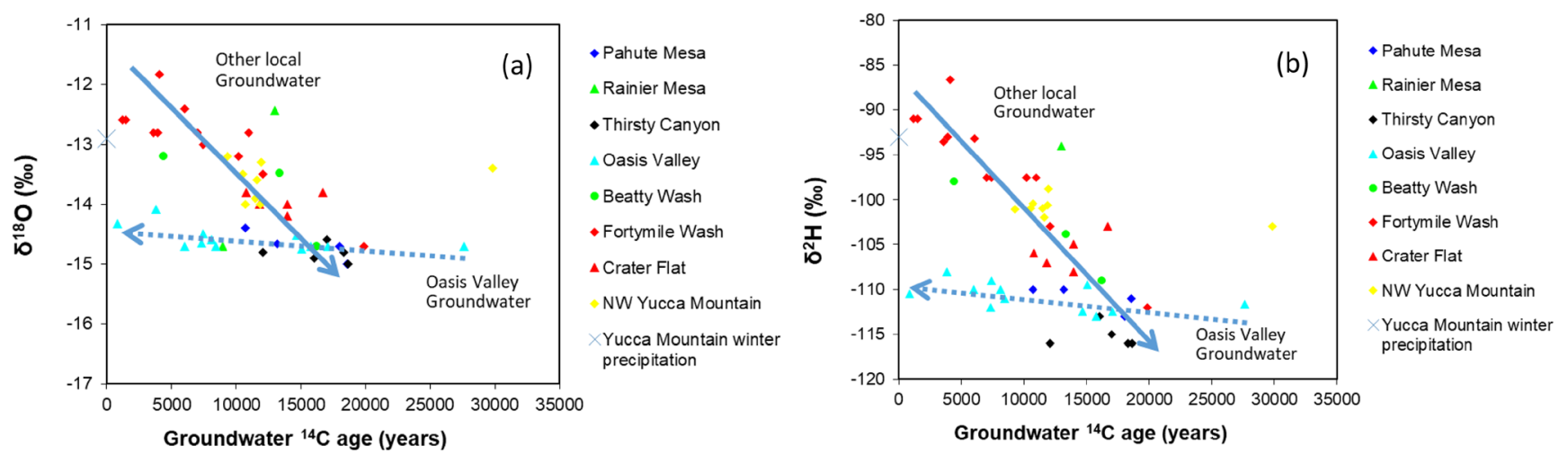

Fig. 10 The relationship between isotopic composition and calculated groundwater ${ }^{14} \mathrm{C}$ age with respect to $\mathbf{a} \delta^{18} \mathrm{O}, \mathbf{b} \delta^{2} \mathrm{H}$ 
Fig. 11 Location of wells within the phase II study area

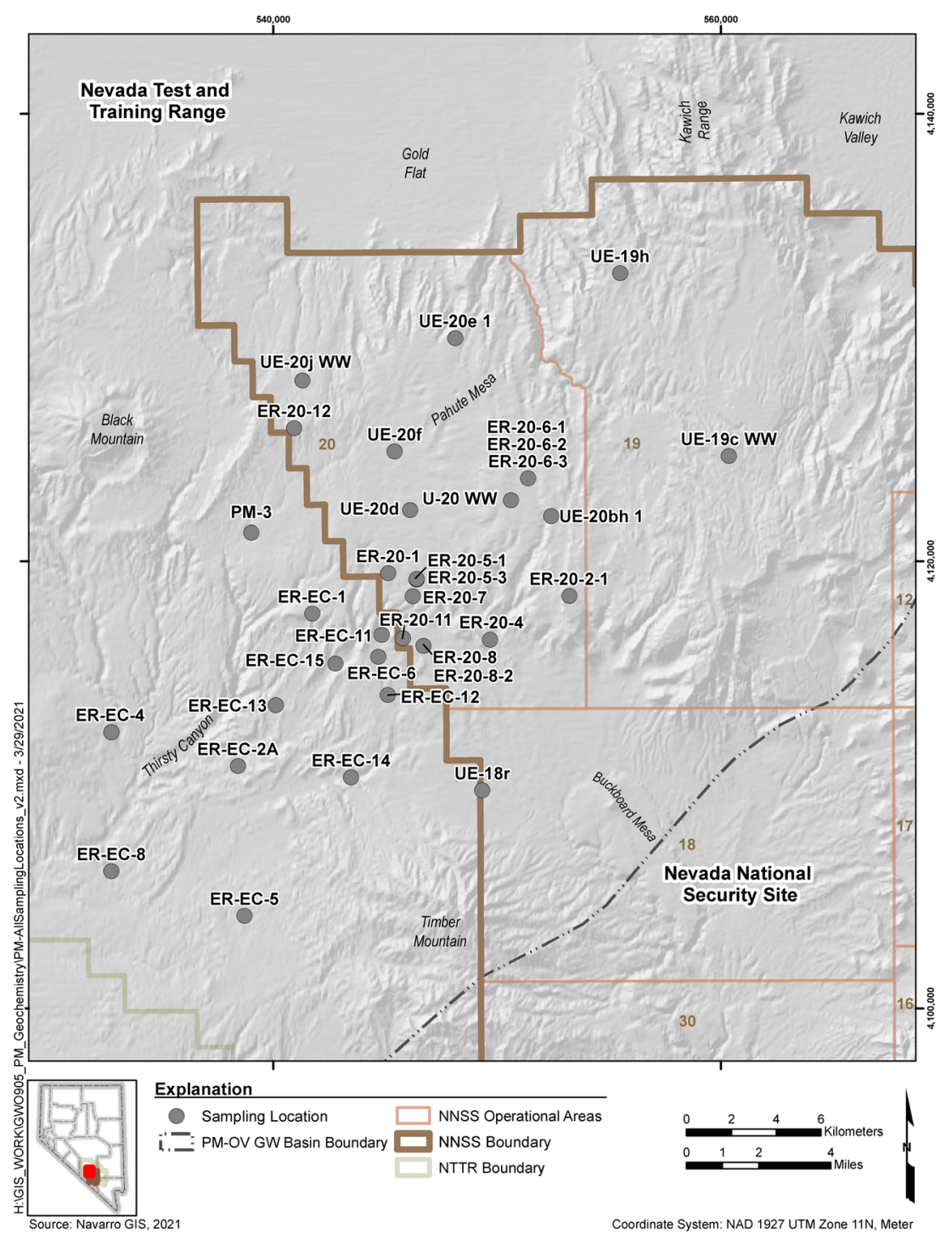

A comprehensive description of this dataset is presented in Navarro (2020). This section presents a summary of this dataset.

\section{Major ions}

A Piper diagram illustrating the relative major-ion concentrations in groundwater samples is presented in Fig. 12. The Piper diagram presents relative concentrations in percent milliequivalents per liter $(\% \mathrm{meq} / \mathrm{L})$ and is used to classify various groundwater chemistry types (or facies) and to illustrate the relationships that may exist between water samples. The relative concentrations of cations and anions are shown in the left and right triangles, respectively, and are projected onto the central diamond to present the combined major-ion chemistry (Fig. 12). The symbol colors are selected to improve visualization of sampling locations that plot close to one another.
The Piper diagram shows that while $\mathrm{Na}+\mathrm{K}$ dominates the cations in all study area groundwaters, the relative concentrations of anions are substantially more variable. Groundwater dominated by $\mathrm{Na}+\mathrm{K}$ is characteristic of waters that have dissolved volcanic rhyolitic lava, ash-fall and ash-flow tuffs, and associated volcanic alluvium (Schoff and Moore 1964; Thomas et al. 2002; Rose et al. 2006). The groundwater ranges from being dominated by $\mathrm{HCO}_{3}$ to having relatively equal concentrations of all three anions $\left(\mathrm{HCO}_{3} / \mathrm{SO}_{4} / \mathrm{Cl}\right)$. The groundwater in the western portion of the study area, identified with blue symbols in Fig. 12, has a distinct major-ion composition $\left(\mathrm{Na}-\mathrm{HCO}_{3} / \mathrm{Cl} / \mathrm{SO}_{4}\right.$ type) which reflects the higher relative concentrations of $\mathrm{Cl}$ and $\mathrm{SO}_{4}$. Although some variability in major-ion chemistry is observed between different completion intervals at a given well (Fig. 12), no clear cut, study-area-wide vertical trends are observed through further evaluation of major-ion data as presented in the ESM. 
Fig. 12 Piper diagram for Pahute Mesa area groundwater samples

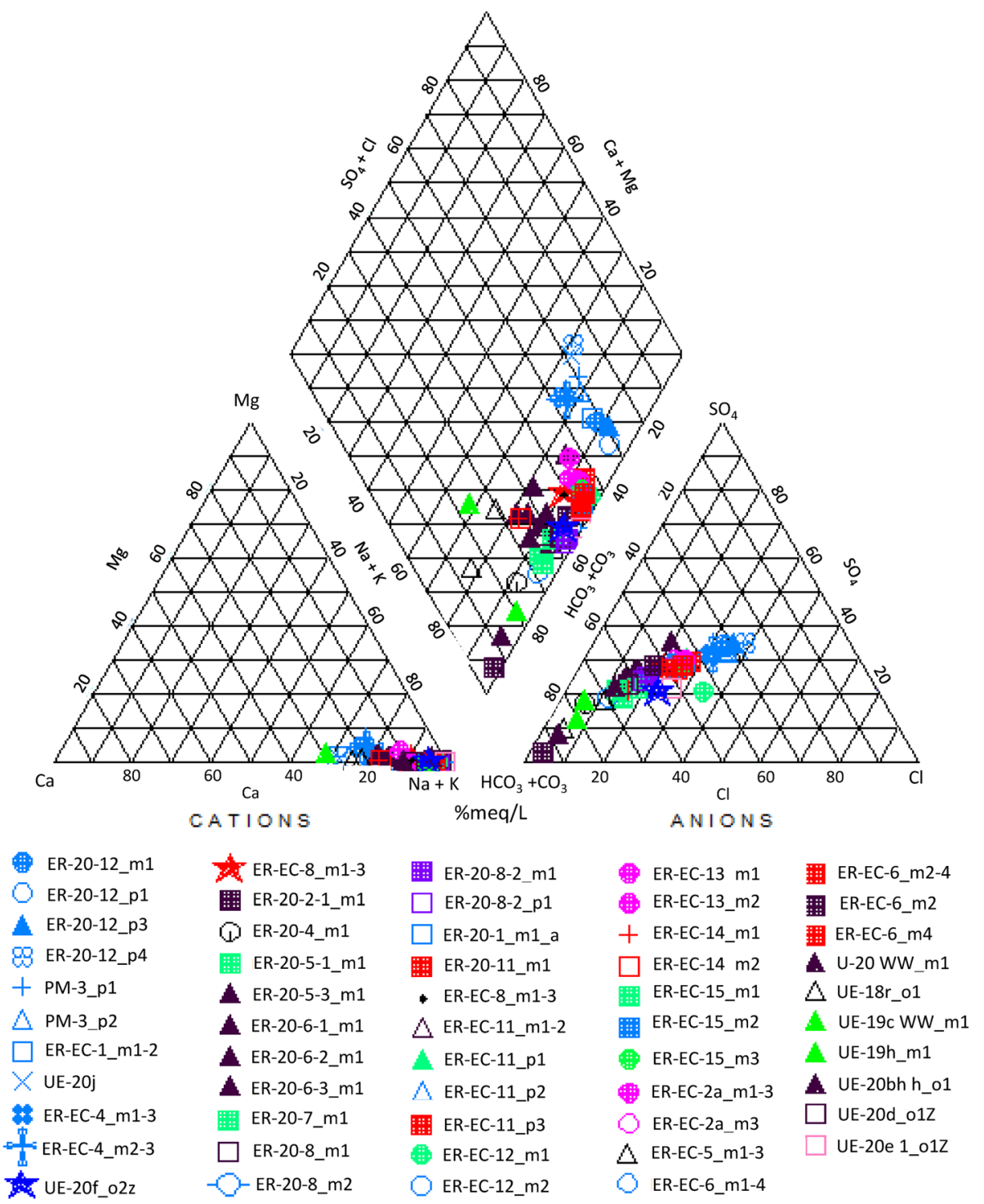

\section{$\delta^{2} H$ and $\delta^{18} 0$}

The $\delta^{2} \mathrm{H}$ and $\delta^{18} \mathrm{O}$ data show very little spatial or depthdependent variability (Navarro 2020). The average $\delta^{2} \mathrm{H}$ of the phase II groundwater samples is $-114 \%$ o with a standard deviation (SD) of $1.65 \%$; the average $\delta^{18} \mathrm{O}$ is $-14.9 \%$ with a $\mathrm{SD}$ of $0.21 \%$. The reported analytical error is $2 \%$ o for $\delta^{2} \mathrm{H}$ and $0.3 \%$ for $\delta^{18} \mathrm{O}$. Because the groundwater $\delta^{2} \mathrm{H}$ and $\delta^{18} \mathrm{O}$ do not show much variation either spatially or with depth, they are not particularly useful as groundwater tracers or indicators of groundwater mixing within the limited geographical area of this study. Like the previous studies, the $\delta^{2} \mathrm{H}$ and $\delta^{18} \mathrm{O}$ data tend to plot below the GMWL (Fig. 9) and are much lighter than present-day high-elevation spring discharge or presentday mean winter precipitation, indicating that they are also associated with recharge under cooler, pluvial-age climates (Navarro 2020).

\section{Dissolved inorganic $\delta^{13} \mathrm{C}$}

Groundwater within the study area has a range of $\delta^{13} \mathrm{C}$ values between about -12 and $0 \%$ o that is related to alkalinity (as $\mathrm{mg} /$ $\mathrm{L} \mathrm{HCO}_{3}$; Fig. 13). The trend of increasing $\delta^{13} \mathrm{C}$ with increasing $\mathrm{HCO}_{3}$ (decreasing inverse $\mathrm{HCO}_{3}$ ) arises through the progressive interaction of groundwater with isotopically heavy calcite fracture coatings as it moves downgradient from high-elevation recharge areas in eastern Pahute Mesa toward Thirsty Canyon. Groundwater samples with relatively low alkalinity (higher inverse alkalinity) have lighter $\delta^{13} \mathrm{C}$ that results from interaction with soil $\mathrm{CO}_{2}$ having a $\delta^{13} \mathrm{C}$ of -20 to $-12 \%$ depending on elevation, type and density of plant cover (Quade et al. 1989). Isotopic analysis of fracture-lining calcite in eastern and western Pahute Mesa show the occurrence of secondary calcite derived from soil $\mathrm{CO}_{2}$ down to

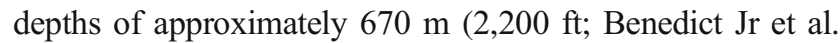




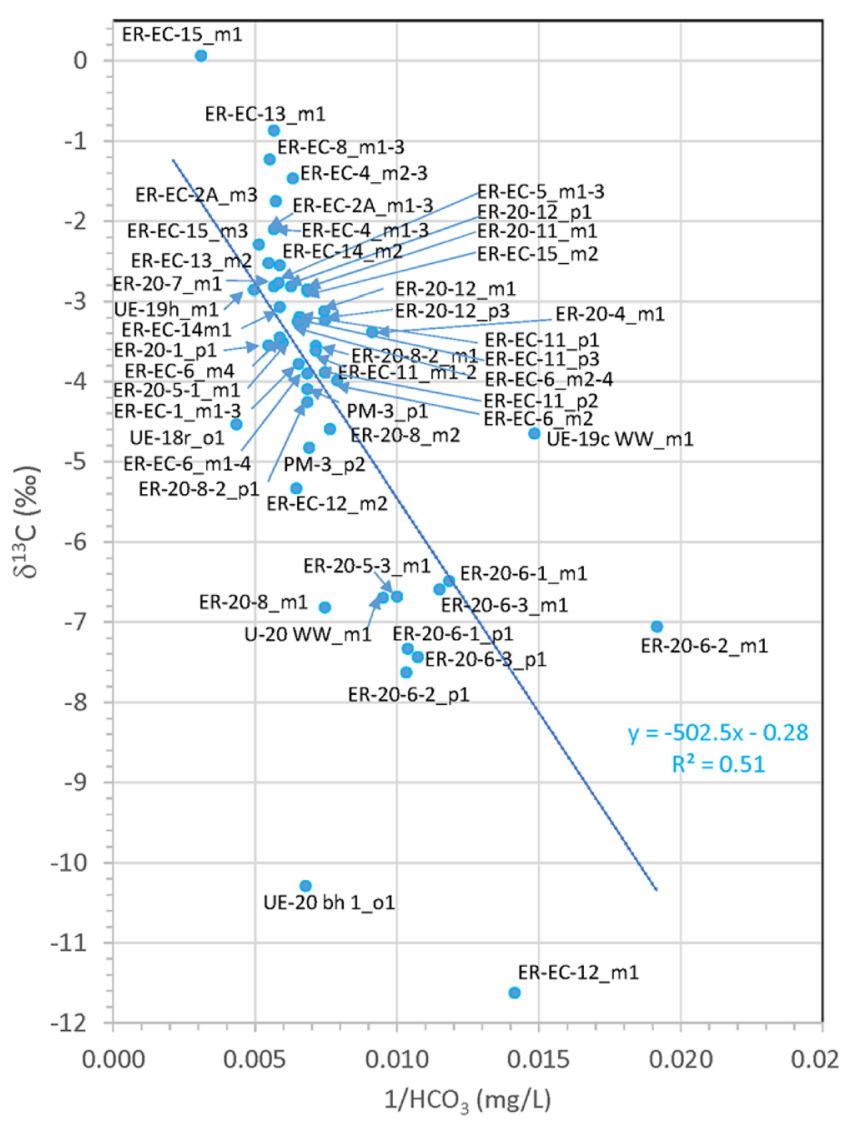

Fig. 13 Scatterplot of $\delta^{13} \mathrm{C}$ versus inverse alkalinity with regression line

2000), a depth which extends to the current water table in many areas. After isotopic fractionation of $\delta^{13} \mathrm{C}$ between the soil gas $\mathrm{CO}_{2}$ and the local water of approximately $+7.9 \%$ o (Clark and Fritz 1997), the resulting groundwater is expected to have a $\delta^{13} \mathrm{C}$ of about -12.1 to $-4.1 \%$. Many groundwater samples in upgradient areas (e.g., UE-20bh 1, ER-20-6 wells, $\mathrm{U}-20 \mathrm{WW}$ ) have $\delta^{13} \mathrm{C}$ values in this range. However, groundwater samples farther downgradient (e.g., ER-EC-12_m2, ER-EC-13, ER-EC-14, ER-EC-15) exhibit much heavier $\delta^{13} \mathrm{C}$ values that reflect interaction with isotopically heavy fracture-lining calcite.

In volcanic rocks in western Pahute Mesa and Thirsty Canyon, fracture-lining calcite with high temperatures of formation $\left(>60^{\circ} \mathrm{C}\right.$, Benedict Jr et al. 2000; Thomas et al. 2002) have $\delta^{13} \mathrm{C}$ values ranging from -3 to $+4 \%$, consistent with the average $\delta^{13} \mathrm{C}$ of the mineral source derived from the $\mathrm{Y}$ intercept of the trend line $\left(\delta^{13} \mathrm{C}=-0.28 \%\right.$ o $)$ at $1 / \mathrm{HCO}_{3}=0$, or infinite concentration (Fig. 13). The $\delta^{13} \mathrm{C}$ and $\delta^{18} \mathrm{O}$ signatures of the fracture-lining calcite along with their high temperature of formation indicate precipitation from groundwater equilibrated with deep Paleozoic carbonate rock under hydrothermal conditions during volcanic activity (Benedict Jr et al. 2000; Thomas et al. 2002), which in the study area occurred more than $8 \mathrm{Ma}$ (Sawyer et al. 1994). That is, the Paleozoic carbonate rock present at the time of volcanism is the likely source of the secondary calcite fracture linings found within the calderas and downgradient in Thirsty Canyon. These fracture-lining calcites currently exhibit textures indicating dissolution by groundwater (IT Corporation 1998), consistent with the interpretation of the trend shown in Fig. 13.

An alternative hypothesis that groundwater $\delta^{13} \mathrm{C}$ values reflect interaction with mantle $\mathrm{CO}_{2}$ was also evaluated but dismissed as part of this study. Mantle-derived $\mathrm{CO}_{2}$ has $\delta^{13} \mathrm{C}$ signatures between -12 and $-2 \%$ (Planavsky et al. 2011), which encompass the range of groundwater values in Pahute Mesa. However, calculated mantle $\mathrm{CO}_{2}$ concentrations based upon ${ }^{3} \mathrm{He} /{ }^{4} \mathrm{He}$ measurements are below 2 millimoles per liter $(\mathrm{mmol} / \mathrm{L})$, and mostly below $0.1 \mathrm{mmol} / \mathrm{L}$, and do not support substantial $\mathrm{CO}_{2}$ input to groundwater from the mantle in the PM-OV groundwater basin (see Navarro 2020).

\section{Dissolved inorganic ${ }^{14} \mathrm{C}$}

Many samples included in this study were collected downgradient of major nuclear tests and were affected by nuclear-test generated ${ }^{14} \mathrm{C}$ (Navarro 2020). The ${ }^{14} \mathrm{C}$ data were therefore unusable for age-dating or estimating groundwater velocities between wells where one or both wells contained test-derived ${ }^{14} \mathrm{C}$. However, even at some wells where no obvious test associated contamination was present, the ${ }^{14} \mathrm{C}$ activities were anomalously high compared to values from the previous studies, suggesting laboratory cross-contamination between the high and low ${ }^{14} \mathrm{C}$ samples or artifacts from chemicals introduced for sample preservation (Navarro 2020). Hence, the ${ }^{14} \mathrm{C}$ data from previous investigations (Kwicklis et al. 2005; Kwicklis 2009) are relied on for groundwater age estimates (Fig. 10). Kwicklis (2009) accounted for groundwater interaction with calcite when estimating ages so that downgradient decreases in ${ }^{14} \mathrm{C}$ reflect only radioactive decay and not water-rock interactions. This approach is consistent with the interpretation of $\delta^{13} \mathrm{C}$ data within the study area.

\section{Data analyses}

\section{Multivariate statistics}

Multivariate statistical analyses of the data were done to identify spatial and depth trends in the data and distinguish groups of wells having similar chemical and isotopic characteristics (see the ESM). These analyses included a correlation matrix between all analytes and two well-clustering analyses: hierarchical and K-means clustering. The correlation matrix revealed associations among the analytes themselves, whereas the clustering techniques identified groupings of wells with similar chemical and isotopic attributes. The strength of these clustering analyses is that they consider all analytes 
simultaneously. However, the interpretations based on the chemical and isotopic data shown in the ESM are nearly identical to those made from $\mathrm{Cl}, \mathrm{SO}_{4}$ and $\delta^{34} \mathrm{~S}$ alone, and for brevity, further discussion will focus on $\mathrm{Cl}, \mathrm{SO}_{4}$ and $\delta^{34} \mathrm{~S}$.

\section{Chloride}

Despite the presence of small amounts of $\mathrm{Cl}$ in volcanic rocks at the NNSS, $\mathrm{Cl}$ is generally assumed to be conservative in volcanic aquifers at the NNSS because (1) small amounts of groundwater-accessible $\mathrm{Cl}$ originally present in the volcanic rocks have long ago been dissolved away; and (2) groundwater $\mathrm{Cl}$ concentrations never approach concentrations at which $\mathrm{Cl}$-based salts will be precipitated. This characteristic of $\mathrm{Cl}$ makes it a useful tracer for tracking groundwater movement and estimating groundwater mixing in the volcanic rocks at Pahute Mesa (Rose et al. 2006; Kwicklis et al. 2005). Spatial variations of dissolved $\mathrm{Cl}$ in groundwater in volcanic rocks and alluvium at the NNSS have typically been attributed to spatial variability in recharge concentrations associated with evaporative concentration of $\mathrm{Cl}$ concentration in the soil zone during infiltration (Meijer 2002), or similar changes in porewater $\mathrm{Cl}$ concentrations associated with long-term climate shifts (Tyler et al. 1996; Walvoord et al. 2002).

Groundwater $\mathrm{Cl}$ concentrations are plotted along with $\mathrm{Cl}$ concentration contours in Fig. 14. For wells with multiple completions, the plot shows the concentration in the shallowest completion interval, and the contouring package (SURFER) used the median value of all completions at the well to create the contour lines. If it is assumed that, once $\mathrm{Cl}$ has entered the groundwater, there are no additional sources of rock $\mathrm{Cl}$ to change the $\mathrm{Cl}$ concentration along a flow path, then the $\mathrm{Cl}$ contour lines shown in Fig. 14 represent potential groundwater flow paths. The assumption that these lines of constant $\mathrm{Cl}$ concentration represent flow paths is supported by their relation to the hydraulic-head contours. In general, the $\mathrm{Cl}$ concentration contours are oriented roughly orthogonal to the contours of hydraulic head, as would be expected for flow paths in an approximately isotropic medium. However, it can be noted that flow paths in the northwest part of the NNSS do not always align perpendicular to head contours, possibly because of the sparsity of head data in this area and the fact that the contouring package assumed continuity in $\mathrm{Cl}$ concentrations across the Purse fault, whereas the hand-drawn hydraulic-head contours, as in past work (Blankennagel and Weir Jr 1973; Laczniak et al. 1996; Fenelon et al. 2016), depict heads in this area as being hydraulically discontinuous across the fault. The potential flow paths represented by the $\mathrm{Cl}$ concentration contours converge from both the northwest and northeast in the hydraulic trough formed in the northwestern portion of the NSSS by the Purse and West Purse faults in the west and the West Boxcar and Boxcar faults in the east (Fig. 14), and then turn sharply west in the northwest TMCC.

\section{${ }^{36} \mathrm{Cl} / \mathrm{cl}$ ratios}

Past geochemical studies (Rose et al. 2006; Kwicklis et al. 2005) have speculated that the high $\mathrm{Cl}$ values in the northwest corner of the NNSS are because of water-rock reactions with hydrothermally altered minerals near an igneous intrusion in the extreme northwest corner of the NNSS (Blankennagel and Weir Jr 1973). To help evaluate this hypothesis, groundwater ${ }^{36} \mathrm{Cl} / \mathrm{Cl}$ versus $1 / \mathrm{Cl}$ data were examined (Fig. 15 ). The data shown in the plot represent naturally occurring ${ }^{36} \mathrm{Cl} / \mathrm{Cl}$ ratios with the possible exception of data from wells ER-EC-6, UE20bh 1, and U-20WW, which contain very low levels of ${ }^{3} \mathrm{H}$ that could indicate the possible presence of small amounts of nuclear-test-generated ${ }^{36} \mathrm{Cl}$ in these samples.

Figure 15 shows that in volcanic rocks at Pahute Mesa, the ${ }^{36} \mathrm{Cl} / \mathrm{Cl}$ ratio is relatively constant across a wide range of $\mathrm{Cl}$ concentrations and generally similar to the estimated presentday ${ }^{36} \mathrm{Cl} / \mathrm{Cl}$ ratios in NNSS-area precipitation of $490 \times 10^{-15}$ (Fabryka-Martin et al. 1993). Figure 15 can be compared with similar plots of ${ }^{36} \mathrm{Cl} / \mathrm{Cl}$ versus $1 / \mathrm{Cl}$ for groundwater from the lower carbonate aquifer (LCA) shown in Moran and Rose (2003) and Kwicklis and Farnham (2014). The ${ }^{36} \mathrm{Cl} / \mathrm{Cl}$ versus $1 / \mathrm{Cl}$ plots in those studies showed a decrease in ${ }^{36} \mathrm{Cl} / \mathrm{Cl}$ ratios with decreasing $1 / \mathrm{Cl}$ (or increasing $\mathrm{Cl}$ concentrations), which indicated that the mineral source of the higher $\mathrm{Cl}$ samples from the LCA had little or no ${ }^{36} \mathrm{Cl}$. The decreasing trend in LCA groundwater was interpreted to indicate groundwater dissolution of ${ }^{36} \mathrm{Cl}$-free $\mathrm{Cl}$ in the carbonate rock matrix. In the case of LCA groundwater, any ${ }^{36} \mathrm{Cl}$ originally present in the carbonate rock would have decayed to near zero since deposition $\sim 300$ million years ago, given the half-life of ${ }^{36} \mathrm{Cl}$ of 301,000 years.

In contrast, the absence of ${ }^{36} \mathrm{Cl} / \mathrm{Cl}$ ratios lower than present-day meteoric ratios of $490 \times 10^{-15}$, even in the highest $\mathrm{Cl}$ concentration groundwater found in wells west of the NNSS (ER-EC-1, ER-EC-4, ER-EC-8, ER-EC-2A), indicates that the source of the high-concentration Pahute Mesa groundwater could not have been the LCA or an ancient hydrothermal mineral source in which the ${ }^{36} \mathrm{Cl}$ would have been largely decayed.

Evidence of ${ }^{36} \mathrm{Cl} / \mathrm{Cl}$ deposition from packrat middens and reconstruction of meteoric ${ }^{36} \mathrm{Cl} / \mathrm{Cl}$ deposition near the NNSS indicates that ${ }^{36} \mathrm{Cl} / \mathrm{Cl}$ ratios in precipitation have varied by a factor of as much as two over the past 40,000 years (Fig. 16; Plummer et al. 1997; Kwicklis and Farnham 2014). As indicated by Fig. 16, meteoric ${ }^{36} \mathrm{Cl} / \mathrm{Cl}$ ratios have been near their present-day values for the past $\sim 10,000$ years, reached a maximum of about twice their present-day values between 10,000 and 15,000 years ago, and were between 40 and $60 \%$ greater than their present-day values between 15,000 and 20,000 years ago. Many of the measured groundwater ${ }^{36} \mathrm{Cl} / \mathrm{Cl}$ ratios are larger than the estimated present-day ratio in precipitation $\left(490 \times 10^{-15}\right)$, consistent with an inferred Pleistocene origin 


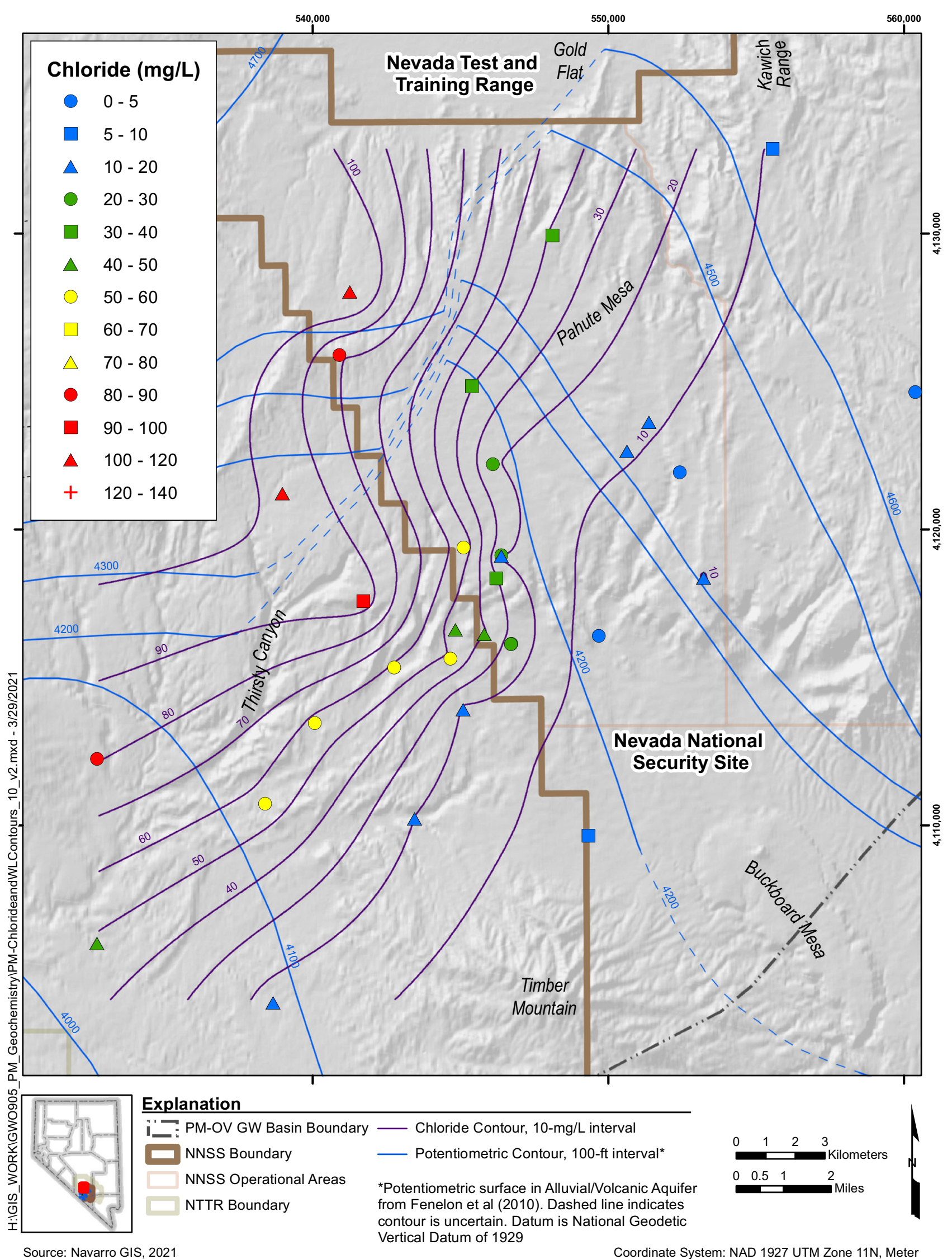

Fig. 14 Chloride and hydraulic-head contours. Hydraulic head contours are from Fenelon et al. (2010) 


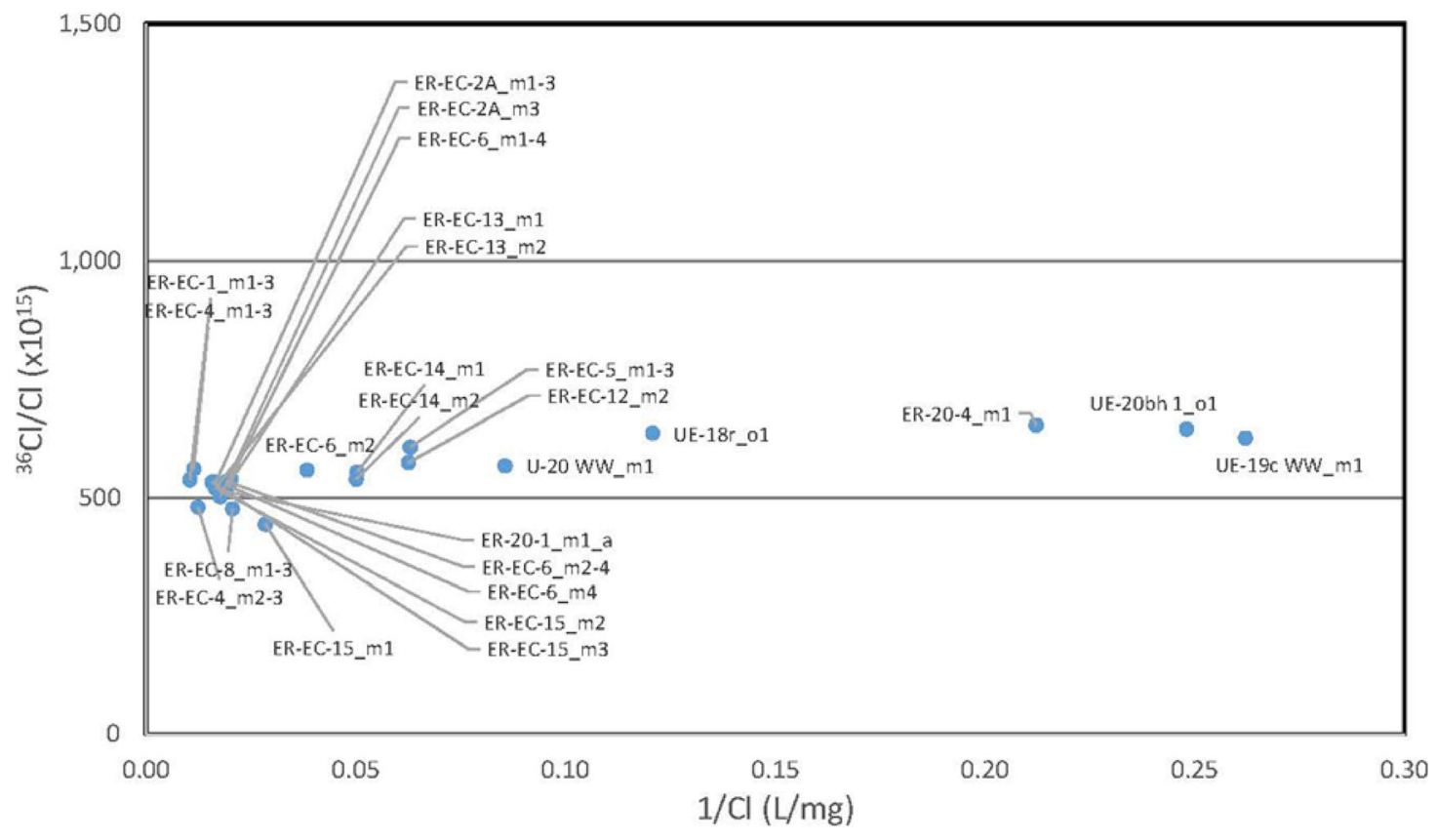

Fig. 15 Plot of ${ }^{36} \mathrm{Cl} / \mathrm{Cl}$ ratios versus inverse $\mathrm{Cl}$ concentration

for the groundwater. This is especially true for the more dilute samples (e.g., from UE-18r, ER-20-4, UE-20bh1, and UE-19c WW), which have ${ }^{36} \mathrm{Cl} / \mathrm{Cl}$ ratios comparable to those estimated for the period 15 to $20 \mathrm{ka}$. However, the highest $\mathrm{Cl}$ concentration samples (e.g., samples from ER-EC-4, ER-EC-8, ER-EC-1, and ER-EC-15) have ${ }^{36} \mathrm{Cl} / \mathrm{Cl}$ ratios roughly comparable to the meteoric ratios shown in Fig. 16 over the last 10,000 years. Thus, the ${ }^{36} \mathrm{Cl} / \mathrm{Cl}$ ratios of the highest $\mathrm{Cl}$ groundwater indicate that either the dissolved $\mathrm{Cl}$ originated from salts deposited in the last 10,000 years, or that the dissolved salts initially had higher ${ }^{36} \mathrm{Cl} / \mathrm{Cl}$ values but are old enough (perhaps hundreds of thousands of years) to have undergone some radioactive decay of ${ }^{36} \mathrm{Cl}$.

\section{Sulfate}

Gradients in dissolved $\mathrm{SO}_{4}$ concentrations shown in Fig. 17 are similar to those observed in $\mathrm{Cl}$ concentrations (Fig. 14). As with $\mathrm{Cl}$, the median value of $\mathrm{SO}_{4}$ at each well was used to create the contour lines for wells with multiple completions. The similarity in the $\mathrm{Cl}$ and $\mathrm{SO}_{4}$ contours is not surprising given the strong correlation $\left(r^{2}=0.93\right)$ between $\mathrm{SO}_{4}$ and $\mathrm{Cl}$ for the study area. As with the plot for $\mathrm{Cl}$, the lines of constant $\mathrm{SO}_{4}$ concentrations can be interpreted as groundwater flow paths if it can be assumed that $\mathrm{SO}_{4}$ is conservative and does not increase or decrease along a flow path because of dissolution or precipitation reactions. As with $\mathrm{Cl}$, the near-orthogonal relation between the $\mathrm{SO}_{4}$ concentration contours and the
Fig. 16 Reconstructed record of past meteoric deposition of ${ }^{36} \mathrm{Cl} /$ $\mathrm{Cl}$ in the vicinity of the NNSS (Source: Kwicklis and Farnham 2014, based on packrat midden data from Plummer et al. 1997)

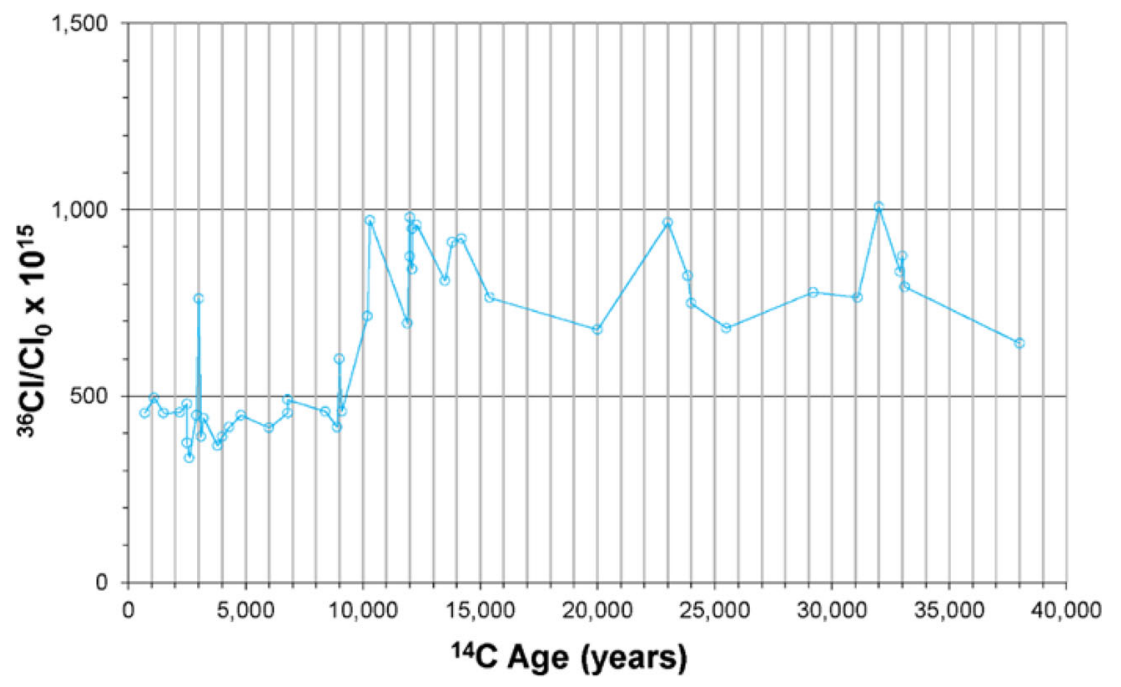




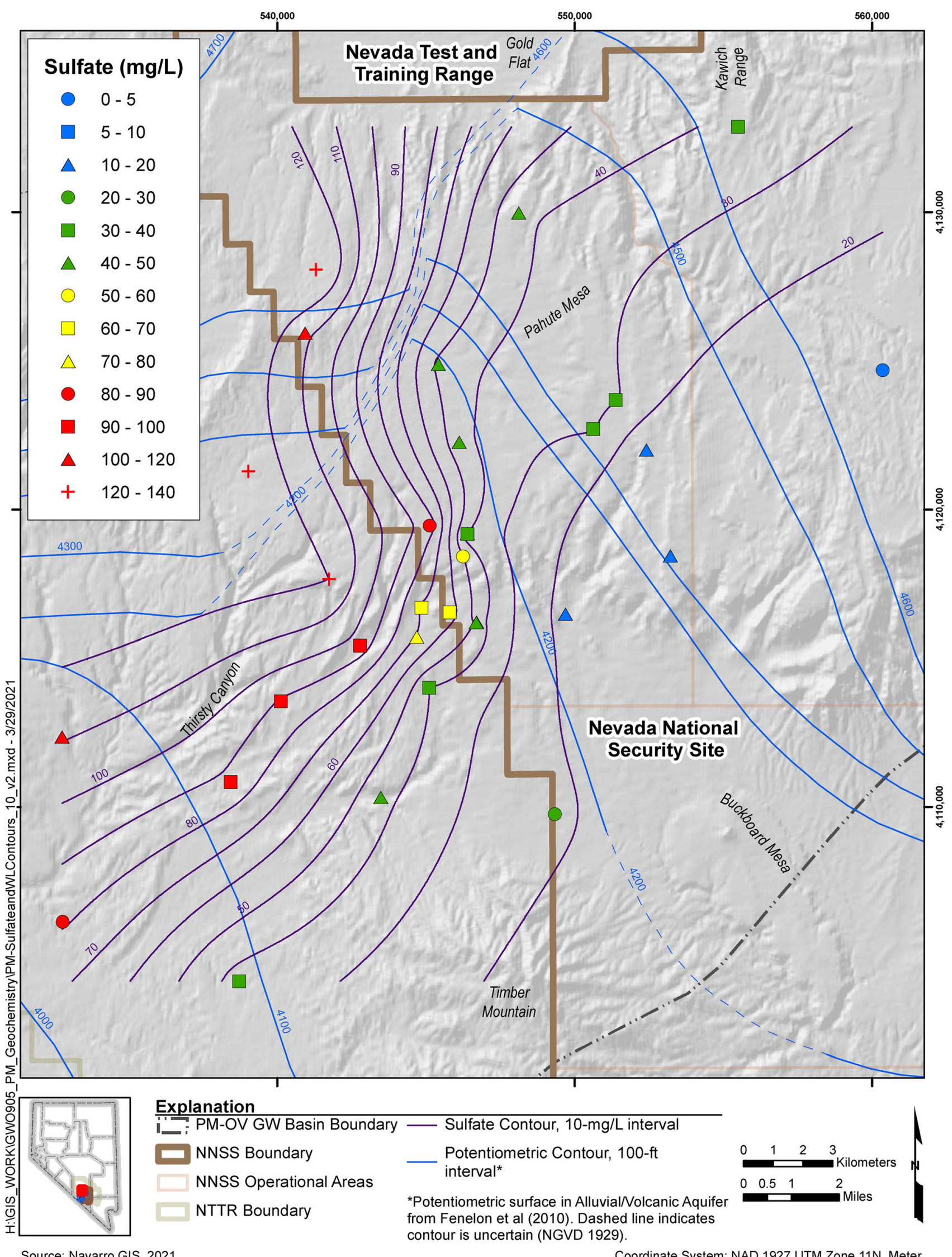

Coordinate System: NAD 1927 UTM Zone 11N, Meter

Fig. 17 Sulfate and hydraulic-head contours. Hydraulic head contours are from Fenelon et al. (2010) 


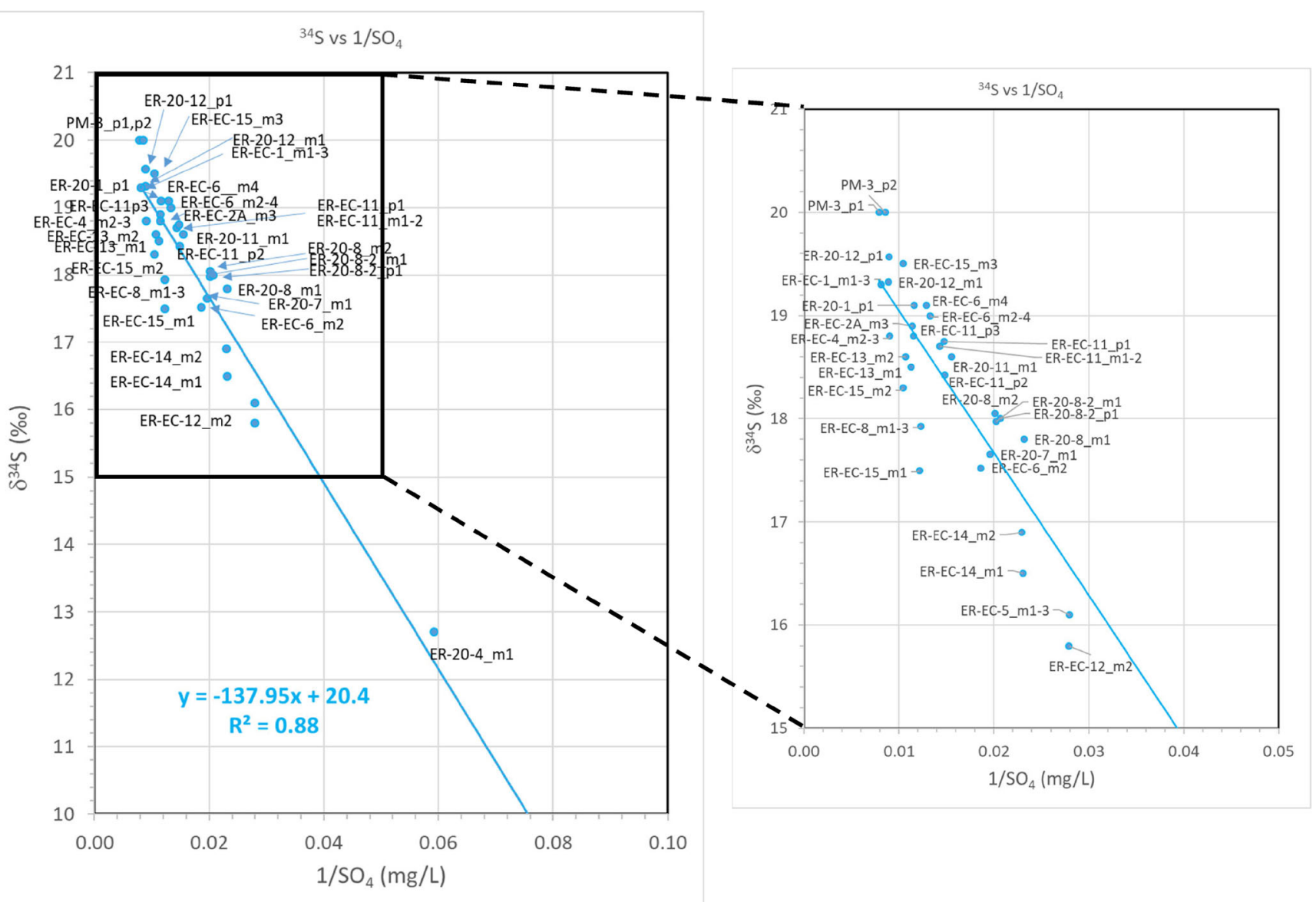

Fig. 18 Scatterplot of $\delta^{34} \mathrm{~S}$ versus $1 / \mathrm{SO}_{4}$ with trend line indicating a mineral source of $\mathrm{S}\left(1 / \mathrm{SO}_{4}=0\right)$ of $\delta^{34} \mathrm{~S}=20.4 \%$ o

contours of hydraulic head are consistent with the hypothesis that lines of constant $\mathrm{SO}_{4}$ concentration also represent flow paths. Except for pyrite $\left(\mathrm{FeS}_{2}\right)$ produced by hydrothermal alteration, there is no known source of sulfur (S) in the volcanic rocks at Pahute Mesa. Pyrite oxidation by groundwater, if it occurs, would tend to increase $\mathrm{SO}_{4}$ concentrations along a flow path. Iron $(\mathrm{Fe})$ staining of fractures surfaces indicates that this process has occurred at some time in the past (Benedict Jr et al. 2000). The strong correlation between $\mathrm{Cl}$ and $\mathrm{SO}_{4}$ indicates similar sources for the high- $\mathrm{SO}_{4}$, high- $\mathrm{Cl}$ water and helps explain the visually similar spatial patterns of dissolved $\mathrm{SO}_{4}$ and $\mathrm{Cl}$ concentrations observed in map view.

\section{Delta sulfur-34}

Sulfur-34/sulfur-32 $\left(\delta^{34} \mathrm{~S}\right)$ ratios of groundwater $\mathrm{SO}_{4}$ were measured on many samples in the study area (Fig. 18). The relationship between $\delta^{34} \mathrm{~S}$ and $1 / \mathrm{SO}_{4}$ indicates that there is a strong trend toward heavier $\delta^{34} \mathrm{~S}$ at higher $\mathrm{SO}_{4}$ concentrations (lower $1 / \mathrm{SO}_{4}$ values). The $\mathrm{y}$-intercept in the fitted regression line is $20.4 \%$. Because $1 / \mathrm{SO}_{4}=0$ at infinite $\mathrm{SO}_{4}$ concentrations, or essentially a solid mineral, the regression line indicates the influence of a mineral S-source with a $\delta^{34} \mathrm{~S}$ of about
$20.4 \%$ o. Although there have been many recent $\delta^{34}$ S measurements reported, the dataset is far from complete as many wells were never sampled for $\delta^{34} \mathrm{~S}$.

As noted earlier, the trend in $\delta^{34} \mathrm{~S}$ versus $1 / \mathrm{SO}_{4}$ in Fig. 18 indicates that groundwater in the study area has interacted with a mineral source of S having a $\delta^{34} \mathrm{~S}$ of $20.4 \%$ o. Clark and Fritz (Clark and Fritz 1997; their Fig. 6-1) shows the observed ranges in $\delta^{34} \mathrm{~S}$ for different minerals, rock types, and environments. The plot indicates that several sources of $\mathrm{S}$ with a $\delta^{34} \mathrm{~S}$ value of roughly $20 \%$ oxist that could serve as the mineral source for the high $\mathrm{SO}_{4}$ groundwater. However, as noted in the discussion of ${ }^{36} \mathrm{Cl} / \mathrm{Cl}$ ratios, the measured groundwater ${ }^{36} \mathrm{Cl} / \mathrm{Cl}$ ratios of the high $\mathrm{Cl}$ groundwater preclude a mineral source for the $\mathrm{Cl}$ of more than a few hundred thousand years old. If $\mathrm{Cl}$ and $\mathrm{SO}_{4}$ are derived from the same source (which their strong correlation with each other suggests), then only one source shown in Clark and Fritz (Clark and Fritz 1997, their Fig. 6-1) is possible as the source of the heavy $\delta^{34} \mathrm{~S}$ in the high $\mathrm{SO}_{4}$ groundwater: modern seawater. Although termed "modern seawater" in Clark and Fritz (1997), the $\delta^{34} \mathrm{~S}$ of seawater has been near $20 \%$ o for the past several million years, despite evidence for large variations in 
the $\delta^{34} \mathrm{~S}$ of seawater in the more distant past (Clark and Fritz 1997, their Fig. 6-2).

\section{Source of the high $\mathrm{Cl}$ and $\mathrm{SO}_{4}$ groundwater}

Both $\mathrm{Cl}$ and $\mathrm{SO}_{4}$ in groundwater appear to be derived from sea spray carried in the wind from the oceans to southern Nevada and deposited in dilute concentrations on the ground during precipitation events. For instance, Meijer (2002) reported that modern precipitation in the Kawich Range has an average dissolved $\mathrm{SO}_{4}$ and $\mathrm{Cl}$ concentration of 0.96 and $0.35 \mathrm{mg} / \mathrm{L}$, respectively. Typically, net infiltration today occurs in upland areas, where the initially dilute infiltrating water is then concentrated by evapotranspiration in the soil zone, before draining below the root zone into bedrock to become net infiltration and, ultimately, groundwater recharge. However, with this mechanism, precipitation would have to become concentrated through evapotranspiration by a factor of several hundred times or more to reach the concentrations observed in the high $\mathrm{Cl}$ and $\mathrm{SO}_{4}$ groundwater $\left(\mathrm{Cl}>100\right.$ and $\mathrm{SO}_{4}>$ $120 \mathrm{mg} / \mathrm{L}$ ). Because this degree of evapotranspiration would leave very little water left to recharge the groundwater, and because the stable isotopes like $\delta^{18} \mathrm{O}$ and $\delta^{2} \mathrm{H}$ do not indicate anything approaching this degree of evaporative fractionation, another mechanism that explains the origin of the high $\mathrm{Cl}$ and $\mathrm{SO}_{4}$ concentration groundwater is required.

One possible explanation that is consistent with all the geochemical and isotopic evidence is the periodic appearance and disappearance of playa lakes in Gold Flat north of Pahute Mesa during the late Pleistocene. The occurrence of such lakes centered around the present-day Gold Flat playa dry lake is documented in Dickerson and Malczyk (2014) based on

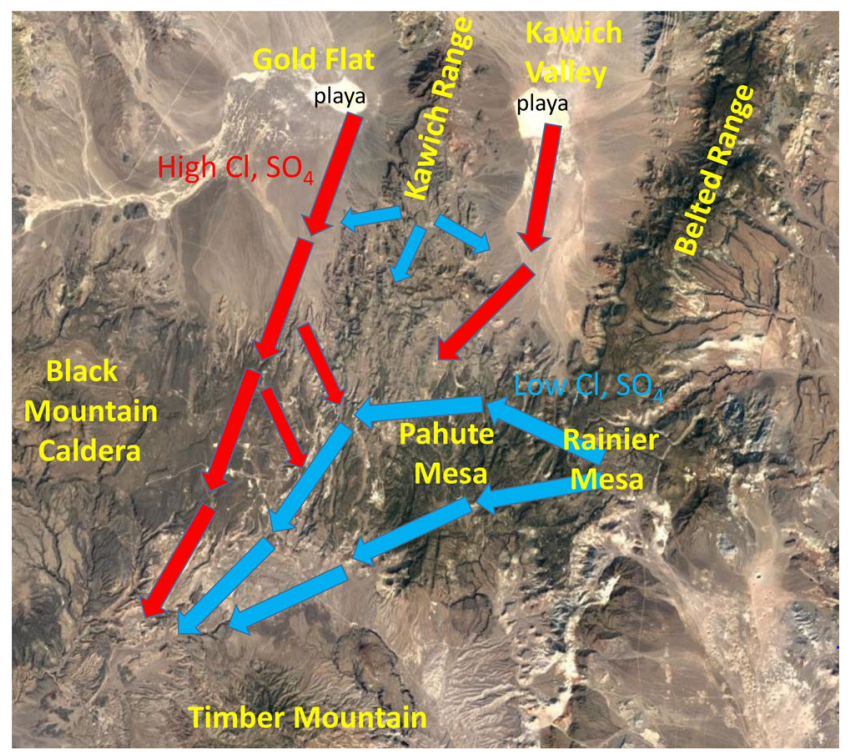

Fig. 19 Conceptual flow paths showing high and low concentration groundwater from Gold Flat and eastern Pahute Mesa converging and mixing in western Pahute Mesa evidence for strandlines and wave-cut benches. Carbon-14 dates from tufa deposits associated with the lake range from 18,200 to 15,620 years (Dickerson and Malczyk 2014), although the lake may have persisted much longer, based on other regional evidence from lakes and wetlands. A similar lake existed in Kawich Valley to the east of the Kawich Range during the late Pleistocene. As the climate oscillated in the late Pleistocene between wetter and drier conditions, playa lakes may have intermittently dried out, leaving deposits of salts containing $\mathrm{Cl}$ and $\mathrm{SO}_{4}$ that were originally derived from sea spray deposited by precipitation. Evaporation would be expected to concentrate ${ }^{36} \mathrm{Cl}$ and ${ }^{35} \mathrm{Cl}$ and ${ }^{34} \mathrm{~S}$ and ${ }^{32} \mathrm{~S}$ equally, leaving the ${ }^{36} \mathrm{Cl} / \mathrm{Cl}$ ratio and $\delta^{34} \mathrm{~S}$ unchanged from the ratios in precipitation. Based on the large concentration increase required to produce salt or gypsum deposits from precipitation, the surface water or groundwater depositing these salts may have largely evaporated as well, leaving little evidence of the highly fractionated water that formed on the playa as it dried out. During the next wet period, the salts deposited during the earlier dry period were dissolved by groundwater as the water table rose to inundate the playa sediments and the previously precipitated salts. The submarine spring deposits near the eastern margin of the playa lake near the Kawich Range were deposited during this relatively wet period. This water would contain high salt concentrations of $\mathrm{Cl}$ and $\mathrm{SO}_{4}$ but have very little evidence for the fractionation of $\delta^{18} \mathrm{O}$ and $\delta^{2} \mathrm{H}$, as would be expected if the high $\mathrm{Cl}$ and $\mathrm{SO}_{4}$ concentrations were due to evapotranspiration of pore water in the root zone. In other words, the surface water that deposited the salts during dry periods and the rising groundwater water that dissolved the salts during wet periods were different waters that occurred at different periods in time. Little evidence of the water that produced the playa deposits exists because of its nearcomplete evapotranspiration during dry intervals; evidence for the dissolution of salts during wet periods is present in the relatively unfractionated, isotopically light, high salinity groundwater that can be observed in wells located west of the NNSS today. It is likely that this high-salinity groundwater was initially recharged at higher elevations in the Kawich Range or other ranges upgradient from Gold Flat playa, and dissolved previously deposited salts as it flowed toward Pahute Mesa beneath the present-day playa. However, the source of the high $\mathrm{Cl}$ and $\mathrm{SO}_{4}$ is still the Gold Flat playa area.

As evident by the trendline in Fig. 18, more dilute $\mathrm{SO}_{4}$ groundwater at Pahute Mesa has a much lower $\delta^{34} \mathrm{~S}$ than the more concentrated groundwater. It is reasonable to ask why the dilute groundwater at Pahute Mesa has a much lower $\delta^{34} \mathrm{~S}$ if sea spray is the source of $\mathrm{S}$ in both the high and low $\mathrm{SO}_{4}$ groundwater. Groundwater $\delta^{34} \mathrm{~S}$ values in the range of +10 to $+15 \%$ also typified dilute groundwater in the volcanic aquifers and alluvium in the nearby Yucca Mountain area (Bechtel and Company 2004). The occurrence of lower $\delta^{34} \mathrm{~S}$ values suggests that in dilute groundwater, small additional mineral 
sources of S can modify the $\delta^{34} \mathrm{~S}$ signature of the salts derived from sea spray. A $\delta^{34} \mathrm{~S}$ value near $+10 \%$ may be a result of very dilute precipitation in the upland recharge areas encountering $\mathrm{FeS}_{2}\left(\delta^{34} \mathrm{~S}\right.$ of $0 \%$ ) in the soil zone. Clark and Fritz (1997) cite studies that show $\delta^{34} \mathrm{~S}$ is further depleted by $2-$ $5.5 \%$ for biologically mediated oxidation of base-metal sulfides like $\mathrm{FeS}_{2}$. The authors of this report hypothesize that soil water with mixed sources of S is then evaporatively concentrated in the soil zone before passing below the root zone to become net infiltration. At Pahute Mesa, this high-elevation dilute groundwater with lower $\delta^{34} \mathrm{~S}$ then moves west, where it encounters the more concentrated groundwater with $\delta^{34} \mathrm{~S}$ near $20 \%$. The mixed groundwater samples then have $\delta^{34} \mathrm{~S}$ values between 13 and $20 \%$, resulting in the trend observed in Fig. 18.

Given this conceptual model, the significance of the groundwater $\mathrm{Cl}$ and $\mathrm{SO}_{4}$ gradients shown in Figs. 14 and 17 now becomes clearer. The large $\mathrm{Cl}$ and $\mathrm{SO}_{4}$ gradient represents the interface between two flow systems (Fig. 19): dilute groundwater moving westward from the higher elevation recharge areas of eastern Pahute Mesa and Rainier Mesa, and the high- $\mathrm{Cl}$, high- $\mathrm{SO}_{4}$ groundwater moving south from playa lakes that formed in Gold Flat during the late Pleistocene. The two flow systems converge and to some degree mix in the southern part of western Pahute Mesa before moving southwestward around the northwest flank of Timber Mountain. The similarity in the $\delta^{18} \mathrm{O}$ and $\delta^{2} \mathrm{H}$ of both the dilute and the more concentrated groundwater, along with their distinctly lighter character compared to modern-day recharge, confirms that both infiltrated under a cooler, pluvial climate. The ${ }^{14} \mathrm{C}$ ages of the groundwater are also consistent with this interpretation (Fig. 10), as are the analysis of noble gas recharge temperatures described in Navarro (2020). The absence of a similar mixing zone in Fig. 19 beneath eastern Pahute Mesa from concentrated groundwater flowing south from the playa in Kawich Valley may be caused by the higher hydraulic heads beneath eastern Pahute Mesa, which would be expected to push Kawich Valley groundwater away from high recharge areas on eastern Pahute Mesa (Figs. 14 and 17). Although the hydraulic head contours shown in Fenelon et al. (2010) are poorly constrained in southern Kawich Valley, Fenelon et al. (2016) and Jackson et al. (2021) argue that flow to the southeast through the low permeability siliciclastic rocks of the Belted Range is implausible and they favor flow out of Kawich Valley in the southwest flow direction, as shown in Fig. 19.

\section{Flow paths}

Groundwater flow paths at Pahute Mesa and downgradient areas were developed during the phase I study based on variations in conservative groundwater tracer data such as those shown in Fig. 8, combined with inverse geochemical modeling to determine if plausible water-rock reactions and mixing could explain the downgradient evolution of both the reactive and conservative species. The datasets included the combined data from both the NNSS and Yucca Mountain repository studies. The inverse geochemical models involved a target downgradient well and a candidate set of upgradient wells suggested by hydraulic gradients and scatterplots of conservative tracer data. The inverse models, which were based on mass-balance constraints, were generally nonunique and provided ranges of mixing ratios and water-rock reactions that could explain the observed chemical and isotopic characteristics of groundwater at the downgradient well. Nonetheless, despite their nonuniqueness, the inverse models greatly limited the number of flow scenarios that are possible. Generally, the initial models considered a downgradient well and the wells immediately upgradient from that well and worked systematically upgradient from
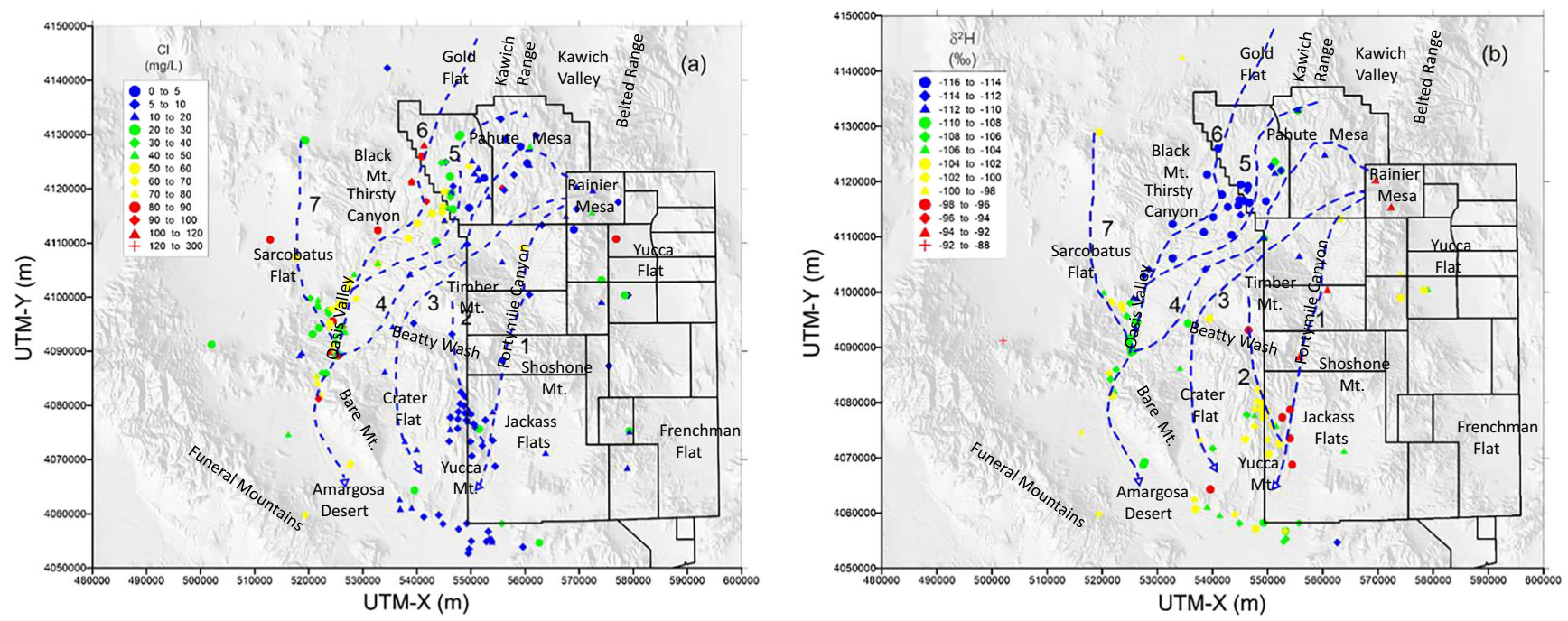

Fig. 20 Revised flow paths shown with $\mathbf{a ~} \mathrm{Cl}$ and $\mathbf{b} \delta^{2} \mathrm{H}$ of wells and springs included in the combined phase I and phase II PM-OV investigation 
there. Flow paths were identified based on the dominant wells involved in the mixing models for the network of wells. Kwicklis et al. (2005) provides summaries of these models for the phase I studies and Navarro (2020) provides these models for the phase II study area. In this section, the groundwater flow paths from Kwicklis et al. (2005) are updated based on new data and interpretations from the phase II study area. Only flow paths 4, 5 and 6 were revised based on the current analysis.

The flow paths are shown superimposed on the combined phase I and phase $\mathrm{II} \mathrm{Cl}$ and $\delta^{2} \mathrm{H}$ in Fig. 20. Although the flow paths are based on detailed geochemical inverse modeling not discussed in detail in this report, the underlying maps of $\mathrm{Cl}$ and $\delta^{2} \mathrm{H}$ data illustrate the basis for several important conclusions regarding flow paths:

- Based on $\mathrm{Cl}$, there is a mixing zone between flow paths 5 and 6 that continues almost to the discharge area at Oasis Valley, where additional flow paths also converge.

- The mixed groundwater at the Oasis Valley discharge area has distinctly heavier $\delta^{2} \mathrm{H}$, indicating the presence of additional groundwater sources besides Pahute Mesa and Thirsty Canyon.

- Groundwater in upper and lower Beatty Wash has distinctly different $\delta^{2} \mathrm{H}$, indicating groundwater does not flow parallel to the wash. Conversely groundwater in Crater Flat has similar $\delta^{2} \mathrm{H}$ as lower Beatty Wash, indicating a potential hydraulic connection between these areas.

- Groundwater south of Timber Mountain in upper Beatty Wash and Yucca Mountain is distinctly heavier in $\delta^{2} \mathrm{H}$ than groundwater at Pahute Mesa, and probably originates from a local source such as recharge on Timber Mountain rather than as underflow from Pahute Mesa beneath Timber Mountain.

The flow paths themselves can be summarized as follows:

- Flow Path 1 represents groundwater flowing from Rainier Mesa along Fortymile Canyon into western Jackass Flat.

- Flow Path 2 is the expected path that Timber Mountain recharge takes as it flows from the recharge area.

- Flow Path 3 represents groundwater flow from Rainier Mesa and eastern Pahute Mesa to the southwest around Timber Mountain and through lower Beatty Wash and into northwest Crater Flat.

- Flow Path 4 represents groundwater from Rainier Mesa flowing southwest around Timber Mountain and through Thirsty Canyon toward the Oasis Valley discharge area

- Flow Path 5 marks the western limit of dilute groundwater flowing from eastern Pahute Mesa. Dilute groundwater moves north-south through southwestern Pahute Mesa and the Bench, and then turns sharply west in the northwest TMCC.

- Flow Path 6 represents groundwater flow from Gold Flat into western Pahute Mesa. This flow path explains the high $\mathrm{Cl}$ and $\mathrm{SO}_{4}$ groundwater observed in western Pahute Mesa.

- Flow Path 7 represents groundwater flowing from northwest Oasis Valley as a minor component in some downgradient Oasis Valley groundwaters.

\section{Summary and conclusions}

Understanding of the groundwater flow system near Pahute Mesa at the NNSS was updated with new groundwater hydrochemical and isotopic data collected as part of a phase II characterization effort. Groundwater flow paths defined by $\mathrm{Cl}$ and $\mathrm{SO}_{4}$ contours indicate convergent flow into a hydraulic trough in western Pahute Mesa that is created by a combination of low- and high-permeability faults. Steep gradients in $\mathrm{Cl}$ and $\mathrm{SO}_{4}$ within this trough reflect the convergence of higherconcentration groundwater flowing south from Gold Flat into western Pahute Mesa, where it mixes with more dilute groundwater flowing west from high-elevation recharge areas in eastern Pahute Mesa and possibly the Belted Range. The groundwater from Gold Flat appears to have been recharged in the late Pleistocene, when the presently dry Gold Flat playa lake alternately dried out and deposited salts, and then redissolved these salts as the playa lake refilled in response to climate oscillations. High stand of the lake was about $30 \mathrm{ft}$. above the present playa surface and occurred between 18 and 15 kya based on ${ }^{14} \mathrm{C}$ dating of submarine tufa deposits, roughly the ${ }^{14} \mathrm{C}$ age of the high- $\mathrm{Cl}$ and $-\mathrm{SO}_{4}$ groundwater presently flowing south along the western boundary of the NNSS. The groundwater hypothesized to be recharged at Gold Flat playa in the late Pleistocene is characterized by ${ }^{36} \mathrm{Cl} / \mathrm{Cl}$ ratios and $\delta^{34} \mathrm{~S}$ values that indicate the elevated $\mathrm{Cl}$ and $\mathrm{SO}_{4}$ in the groundwater originated from salts derived from the ocean and deposited with precipitation in the late Pleistocene, rather than from an ancient mineral source such as a hydrothermal deposit. The extremely light $\delta^{18} \mathrm{O}$ and $\delta^{2} \mathrm{H}$ of this groundwater relative to modern precipitation is also consistent with a late pluvial origin for the groundwater. The dilute groundwater flowing west from eastern Pahute Mesa is also late Pleistocene groundwater based on its ${ }^{14} \mathrm{C}$ age and its similarly light $\delta^{18} \mathrm{O}$ and $\delta^{2} \mathrm{H}$ relative to modern precipitation. The continued presence of late Pleistocene groundwater beneath Pahute Mesa, despite evidence for a dynamic saturated flow system from the rapid migration of nuclear-test-generated ${ }^{3} \mathrm{H}$, is attributed to long residence times of high-elevation infiltration in the thick $(>600-\mathrm{m})$ unsaturated zone beneath Pahute Mesa. In the case of the more concentrated pluvial playa lake 
groundwater, its continued presence beneath western Pahute Mesa is attributed to the small volume of recharge north of Pahute Mesa that is presently available to displace the Pleistocene groundwater, and to the slow transport out of Gold Flat through high-porosity alluvium.

In general, groundwater velocity estimates from ${ }^{14} \mathrm{C}$ could not be made. Groundwater ${ }^{14} \mathrm{C}$ often included contributions of test-derived ${ }^{14} \mathrm{C}$, which biased the travel-time estimates between wells. Downgradient of the areas affected by testderived ${ }^{14} \mathrm{C}$, past studies (e.g., Kwicklis 2009) have concluded that either the difference between ${ }^{14} \mathrm{C}$ activities was too small to allow reliable travel-time estimates or, close to Oasis Valley discharge areas, groundwater had interacted with ${ }^{14} \mathrm{C}$ in soil $\mathrm{CO}_{2}$, which reset the groundwater ${ }^{14} \mathrm{C}$ ages and caused the shallow groundwater to appear artificially young. Estimated noble gas recharge temperatures and ${ }^{3} \mathrm{He} /{ }^{4} \mathrm{He}$ ratios generated as part of this study and reported in Navarro (2020) support the hypothesis that groundwater re-equilibrated with shallow soil gas in the Oasis Valley area.

In general, the groundwater geochemical and isotopic data support the interpretation from hydrologic and geologic data that groundwater from testing areas on Pahute Mesa does not flow directly south from Pahute Mesa beneath Timber Mountain toward Yucca Mountain, but instead flows around the northwest margin of Timber Mountain toward Oasis Valley and lower Beatty Wash. Some unknown, but probably minor, fraction of this groundwater flows across lower Beatty Wash into northwest Crater Flat, but most flows toward Oasis Valley as indicated by hydraulic-head contours. Steep hydraulic gradients between Beatty Wash and areas to the south indicate that southerly flow beneath Timber Mountain is prevented by structural or stratigraphic features to the south of Timber Mountain rather than beneath Timber Mountain itself. Groundwater south of Timber Mountain in upper Beatty Wash and northwest Yucca Mountain has distinctly heavier $\delta^{18} \mathrm{O}$ and $\delta^{2} \mathrm{H}$ than Pahute Mesa groundwater and was probably derived by local recharge on Timber Mountain itself.

Supplementary Information The online version contains supplementary material available at https://doi.org/10.1007/s10040-021-02397-x.

Acknowledgements Rebecca Frus of the US Geological Survey is thanked for providing the $\delta^{34} \mathrm{~S}$ data used in this paper.

Funding The authors would like to thank Bill Wilborn and John Myers of the US Department of Energy Environmental Management Nevada Program for funding this study.

Open Access This article is licensed under a Creative Commons Attribution 4.0 International License, which permits use, sharing, adaptation, distribution and reproduction in any medium or format, as long as you give appropriate credit to the original author(s) and the source, provide a link to the Creative Commons licence, and indicate if changes were made. The images or other third party material in this article are included in the article's Creative Commons licence, unless indicated otherwise in a credit line to the material. If material is not included in the article's Creative Commons licence and your intended use is not permitted by statutory regulation or exceeds the permitted use, you will need to obtain permission directly from the copyright holder. To view a copy of this licence, visit http://creativecommons.org/licenses/by/4.0/.

\section{References}

Bechtel SAIC Company LLC (2004) Geochemical and isotopic constraints on groundwater flow directions, mixing, and recharge at Yucca Mountain, Nevada. ANL-NBS-HS-000021, rev. 00, US Department of Energy, National Nuclear Security Administration Nevada Site Office, Las Vegas, NV

Benedict FC Jr, Rose TP, Zhou X (2000) Mineralogical, chemical, and isotopic characterization of fracture-coating minerals in borehole samples from western Pahute Mesa and Oasis Valley, Nevada. UCRL-ID-152919, Lawrence Livermore National Laboratory, Livermore, CA

Benson LV, Klieforth H (1989) Stable isotopes in precipitation and groundwater in the Yucca Mountain region, southern Nevada: paleoclimatic implications. In: Peterson DH (ed) Aspects of climate variability in the Pacific and western Americas. Am Geophys Union Geophys Monogr 55:41-59

Blankennagel RK, Weir JE Jr (1973) Geohydrology of the eastern part of Pahute Mesa, Nevada Test Site, Nye County, Nevada. US Geol Surv Prof Pap 712-B

Carlos BA, Chipera SJ, Bish DL (1995) Distribution and chemistry of fracture-lining minerals at Yucca Mountain, Nevada. LA-12977-MS report, Los Alamos National Laboratory, Los Alamos, NM

Claassen HC (1985) Sources and mechanisms of recharge for ground water in the west-central Amargosa Desert, Nevada: a geochemical interpretation. US Geol Surv Prof Pap 712-F

Clark I, Fritz P (1997) Environmental isotopes in hydrogeology. CRC, Boca Raton, FL

Code of Federal Regulations (2019) Title 40 CFR, part 141. National Primary Drinking Water Regulations, US Government Printing Office, Washington, DC

Craig H (1961) Isotopic variations in meteoric waters. Science 133(3465):1702-1703

Dickerson R, Malczyk N (2014) Quaternary geologic studies on playas of the Nevada Test and Training Range in support of the Nellis Air Force Base Training Mission. Geological Society of America Annual Meeting, vol 40, no. 6, Houston, October 2008

Fabryka-Martin JT, Wightman SJ, Murphy WJ, Wickham MP, Caffee MW, Nimz GJ, Southon JR, Sharma P (1993) Distribution of Chlorine-36 in the unsaturated zone at Yucca Mountain: an indicator of fast transport paths. In: Conference proceedings, FOCUS'93: site characterization and model validation, Las Vegas, NV, 26-29 September

Fenelon JM, Sweetkind DS, Laczniak RJ (2010) Groundwater flow Systems at the Nevada Test Site, Nevada: a synthesis of potentiometric contours, hydrostratigraphy, and geologic structures. US Geol Surv Prof Pap 1771

Fenelon JM, Halford KJ, Moreo MT (2016) Delineation of the Pahute Mesa-Oasis Valley Groundwater Basin, Nevada, version 11. US Geol Surv Sci Invest Rep 2015-5175

Finnegan DL, Bowen SM, Thompson JL, Miller CM, Baca PL, Olivas LF, Geoffrion CG, Smith DK, Goishi W, Esser BK, Meadows JW, Namboodiri N, Wild JF (2016) Nevada National Security Site 
Underground Radionuclide Inventory, 1951-1992: accounting for radionuclide decay through September 30, 2012. LA-UR-16-21749, Los Alamos National Laboratory, Los Alamos, NM

Flint AL, Flint LE, Hevesi JA, Blainey JB (2004) Fundamental concepts of recharge in the desert southwest: a regional modeling perspective in groundwater recharge in a desert environment - the Southwestern United States. American Geophysical Union, Washington, DC

Forester RM, Bradbury JP, Carter C, Elvidge-Tuma AB, Hemphill ML, Lundstrom SC, Mahan SC, Marshall BD, Neymark LA, Paces JB, Sharpe SE, Whelan JF, Wigand PE (1999) The climatic and hydrologic history of southern Nevada during the Late Quaternary. US Geol Surv Open-File Rep 98-635

Frus RJ, Halford KJ (2018) Documentation of single-well aquifer tests and integrated borehole analyses, Pahute Mesa and vicinity, Nevada. US Geol Surv Sci Invest Rep 2018-5096

Garcia CA, Jackson TR, Halford KJ, Sweetkind DS, Damar NA, Fenelon JM, Reiner SR (2017) Hydraulic characterization of volcanic rocks in Pahute Mesa using an integrated analysis of 16 multiple-well aquifer tests, Nevada National Security Site, 2009-14. US Geol Surv Sci Invest Rep 2016-5151

Halford KJ, Jackson TR (2020) Groundwater characterization and effects of pumping in the Death Valley regional groundwater flow system, Nevada and California, with special reference to Devils Hole. US Geol Surv Prof Pap 1863

Hershey RL, Thomas JM, Rose TP, Paces JB, Farnham IM, Benedict FC $\mathrm{Jr}$ (2005) Evaluation of groundwater movement in the Frenchman Flat CAU using geochemical and isotopic analysis. DOE/NV/ 13609-36, no. 45207, Desert Research Institute, Las Vegas, NV

Hershey RL, Paces JB, Singleton MJ, Kwicklis EM, Decker DL, Fryer WM, Earman S (2008) Geochemical and isotopic evaluation of groundwater movement in corrective action unit 99: Rainier Mesa and Shoshone Mountain, Nevada Test Site. DOE/NV/26383-10, no. 45229, Desert Research Institute, Las Vegas, NV

Hershey RL, Parashar R, Cooper CA, Heintz KM, Pham HV, Lyles BF (2020) Evaluation of Timber Mountain recharge and groundwater flow in relation to Pahute Mesa-Oasis Valley flow system. DOE/ NV/0003590-56, no. 45294, Desert Research Institute, Las Vegas, NV

Ingraham NL, Lyles BF, Jacobson RL, Hess JW (1991) Stable isotopic study of precipitation and spring discharge in southern Nevada. $\mathrm{J}$ Hydrol 125(3-4):243-258

IT Corporation (1998) Summary of micrographic analysis of fracture coating phases on drill cores from Pahute Mesa, Nevada Test Site. DOE/NV/13052-050-Rev. 1; ITLV/13052-050-Rev. 1, Desert Research Institute, Las Vegas, NV

Jackson TR, Fenelon JM, Paylor R (2021) Groundwater flow conceptualization of the Pahute Mesa-Oasis Valley groundwater basin, Nevada: a synthesis of geologic, hydrologic, hydraulic-property, and tritium data. US Geol Surv Sci Invest Rep 2020-5134, plate 1. https://doi.org/10.3133/sir20205134

Kwicklis E (2009) Appendix D: Evaluation of groundwater travel times in the PM-OV flow system from $14 \mathrm{C}$ data in phase I transport model of corrective action units 101 and 102: central and Western Pahute Mesa, Nevada Test Site, Nye County, Nevada. S-N/99205-111, Stoller-Navarro Joint Venture, Las Vegas, NV

Kwicklis E, Farnham I (2014) Testing the 14C ages and conservative behavior of dissolved $14 \mathrm{C}$ in a carbonate aquifer in Yucca Flat, Nevada (USA), using ${ }^{36} \mathrm{Cl}$ from groundwater and packrat middens. Hydrogeol J 22(6):1359-1381

Kwicklis EM, Rose TP, Benedict FC Jr (2005) Evaluation of groundwater flow in the Pahute Mesa-Oasis Valley flow system using groundwater chemical and isotopic data. LA-UR-05-4344, Los Alamos National Laboratory, Los Alamos, NV

Laczniak RJ, Cole JC, Sawyer DA, Trudeau DA (1996) Summary of Hydrogeologic controls on ground-water flow at the Nevada test site, Nye County, Nevada. US Geol Surv Sci Invest Rep 96-4109
Meijer A (2002) Conceptual model of the controls on natural water chemistry at Yucca Mountain, Nevada. Appl Geochem 17(6):793-805

Merlivat L, Jouzel J (1979) Global climatic interpretation of the deuterium-oxygen-18 relationship for precipitation. J Geophys Res 84:5029-5033

Middleton RS, Kwicklis EM, Birdsell KH, Levitt DG, Hevesi J (2019) Net infiltration models for the Pahute Mesa area. LA-UR-16-27513, rev 1, Los Alamos National Laboratory, Los Alamos, NM

Moran JE, Rose TP (2003) A chlorine-36 study of regional groundwater flow and vertical transport in southern Nevada. Environ Geol 43(5): 592-605

Moscati RJ, Scofield KM (2011) Meteoric precipitation at Yucca Mountain, Nevada: chemical and stable isotope analyses. US Geol Surv Sci Invest Rep 2006-09, 16 pp

Navarro (2019) UGTA geochemistry database. UGTA technical data repository database identification number UGTA-4-129, Navarro, Las Vegas, NV

Navarro (2020) Phase II geochemical and isotopic evaluation of groundwater flow in the Pahute Mesa-Oasis Valley flow system, Nevada. Rev 0, N0002653-069, Navarro, Las Vegas, NV

Parkhurst DL, Appelo CAJ (1999) User's guide to PHREEQC (version 2: a computer program for speciation, batch-reaction, one-dimensional transport, and inverse geochemical calculations. US Geol Surv Water Resour Invest Rep 99-4259

Planavsky N, Partin CA, Bekker A (2011) Carbon isotopes as a geochemical tracer. In: Encyclopedia of astrobiology. Springer, Heidelberg, Germany, pp 241-245

Plummer LN, Prestemon EC, Parkhurst DL (1994) An interactive code (NETPATH) for modeling net geochemical reactions along a flow path, version 2.0. US Geol Surv Water Resour Invest Rep 94-4169

Plummer MA, Phillips FM, Fabryka-Martin J, Turin HJ, Wigand PE, Sharma P (1997) Chlorine-36 in fossil rat urine: an archive of Cosmogenic nuclide deposition during the past 40,000 years. Science 277(5325):538-541

Prothro LB, Drellack SL, Mercadante JM (2009) A Hydrostratigraphic system for modeling groundwater flow and radionuclide migration at the corrective action unit scale, Nevada test site and surrounding areas, Clark, Lincoln, and Nye counties, Nevada. DOE/NV/25946630, National Security Technologies, Las Vegas, NV

Quade J, Cerling TE, Bowman JR (1989) Systematic variations in the carbon and oxygen isotopic composition of Pedogenic carbonate along elevation transects in the southern Great Basin, United States. Geol Soc Am Bull 101(4):464-475

Reiner SR, Laczniak RJ, DeMeo GA, Smith JL, Elliott PE, Nylund WN, Fridrich CJ (2002) Ground-water discharge determined from measurements of evapotranspiration, other available hydrologic components, and shallow water-level changes, Oasis Valley, Nye County, Nevada. US Geol Surv Water Resour Invest Rep 01-4239

Rose TP, Benedict FC Jr, Thomas JM, Sicke WS, Hershey RL, Paces JB, Farnham IM, Peterman ZE (2006) Geochemical data analysis and interpretation of the Pahute Mesa-Oasis Valley groundwater flow system, Nye County, Nevada. UCRL-TR-224559, Lawrence Livermore National Laboratory, Livermore, CA

Russell CE, Minor T (2002) Reconnaissance estimates of recharge based on an elevation-dependent chloride mass-balance approach. DOE/ NV/11508-37, no. 45164, Desert Research Institute, Las Vegas, NV

Sawyer DA, Fleck RJ, Lanphere MA, Warren RG, Broxton DE, Hudson MR (1994) Episodic caldera volcanism in the Miocene southwestern Nevada volcanic field: revised stratigraphic caldera framework, 40Ar/39Ar geochronology, and implications for magmatism and extension. Geol Soc Am Bull 106(10):1304-1318

Schoff SL, Moore JE (1964) Chemistry and movement of ground water, Nevada Test Site. US Geol Surv Open File Rep 138

Stoller-Navarro Joint Venture (2006) Geochemical and isotopic evaluation of groundwater movement in corrective action unit 97: Yucca 
Flat/Climax Mine, Nevada Test Site, Nevada. Rev 0, S-N/99205070, Stoller-Navarro Joint Venture, Las Vegas, NV

Thomas JM, Benedict FC Jr, Rose TP, Hershey RL, Paces JB, Peterman ZE, Farnham IM, Johannesson KH, Singh AK, Stetzenbach KJ, Hudson GB, Kenneally JM, Eaton GF, Smith DK (2002) Geochemical and isotopic interpretations of groundwater flow in the Oasis Valley flow system, southern Nevada. DOE/NV/1150856, no. 45190, Desert Research Institute, Las Vegas, NV

Tyler SW, Chapman JB, Conrad SH, Hammermeister DP, Blout DO, Miller JJ, Sully MJ, Ginanni JM (1996) Soil-water flux in the southern Great Basin, United States: temporal and spatial variations over the last 120,000 years. Water Resour Res 32(6)1481-1499

US Department of Energy (2019) Record of technical change to Nevada National Security Site Integrated Groundwater Sampling Plan. DOE/NV-1525-REV 1; ROTC No DOE/NV-1525-REV1-ROTC 1, US Department of Energy Environmental Management Nevada Program, Las Vegas, NV

US Department of Energy Environmental Management Nevada Program (2020) Written communication subject: Pahute Mesa-Oasis Valley Hydrostratigraphic framework model for corrective action units 101 and 102: central and Western Pahute Mesa, Nye County Nevada. US Department of Energy Environmental Management Nevada Program, Las Vegas, NV

US Department of Energy, National Nuclear Security Administration Nevada Field Office (2015) United States nuclear tests, July 1945 through September 1992. DOE/NV-209-REV 16, US Department of Energy, National Nuclear Security Administration Nevada Field Office, Las Vegas, NV

Vaniman DT, Chipera SJ, D1 B, Carey JW, Levy SS (2001) Quantification of unsaturated-zone alteration and cation exchange in zeolitized tuffs at Yucca Mountain, Nevada, USA. Geochim Cosmochim Acta 65(20):3409-3433

Walvoord MA, Phillips FM, Tyler SW, Hartsough PC (2002) Deep arid system hydrodynamics, 2: application to paleohydrologic reconstruction using vadose zone profiles from the northern Mojave Desert. Water Resour Res 38(12):27-1-27-12

Warren RG, Sawyer DA, Byers FM Jr, Cole GL (2003) A petrographic, geochemical and geophysical database and stratigraphic framework of the southwestern Nevada volcanic field. LA-UR-03-1503 Los Alamos. Report, Los Alamos National Laboratory, Los Alamos, NM

White AF, Chuma NJ (1987) Carbon and isotopic mass balance models of Oasis Valley-Fortymile Canyon groundwater basin, southern Nevada. Water Resour Res 23(4):571-582

White AF, Claassen HC, Benson LV (1980) The effect of dissolution of volcanic glass on the water chemistry in a tuffaceous aquifer. US Geol Surv Water Supply Pap 1535-Q

Winograd IJ, Coplen TB, Landwehr JM, Riggs AC, Ludwig KR, Szabo BJ, Kolesar PT, Revesz KM (1992) Continuous 500,000-year climate record from vein calcite in Devils Hole, Nevada. Science 258(5080):255-260

Winograd IJ, Riggs AC, Coplen TB (1998) The relative contributions of summer and cool-season precipitation to groundwater recharge, Spring Mountains, Nevada, USA. Hydrogeol J 6(1):77-93

Winograd IJ, Landwehr JM, Coplen TB, Sharp WD, Riggs AC, Ludwig KR, Kolesar PT (2006) Devils Hole, Nevada, $\delta^{18} \mathrm{O}$ record extended to the mid-Holocene. Quat Res 66(2):202-212

Winograd IJ, Thordarson W (1975) Hydrogeologic and hydrochemical framework, south-central Great Basin, Nevada-California, with special reference to the Nevada Test Site. US Geol Surv Prof Pap 712C, $126 \mathrm{pp}$

Yang IC, Rattray GW, Pei Y (1996) Interpretation of chemical and isotopic data from boreholes in the unsaturated zone at Yucca Mountain, Nevada. US Geol Surv Water Resour Invest Rep 96$4058,58 \mathrm{pp}$

Publisher's note Springer Nature remains neutral with regard to jurisdictional claims in published maps and institutional affiliations. 